\title{
LEVEL II SCOUR ANALYSIS FOR BRIDGE 6 (VICTTH00010006) on TOWN HIGHWAY 1, crossing the MOOSE RIVER, VICTORY, VERMONT
}

U.S. Geological Survey Open-File Report 97-6

Prepared in cooperation with

VERMONT AGENCY OF TRANSPORTATION and

FEDERAL HIGHWAY ADMINISTRATION 


\section{LEVEL II SCOUR ANALYSIS FOR BRIDGE 6 (VICTTH00010006) on TOWN HIGHWAY 1, crossing the MOOSE RIVER, VICTORY, VERMONT \\ By SCOTT A. OLSON}

U.S. Geological Survey Open-File Report 97-6

Prepared in cooperation with

VERMONT AGENCY OF TRANSPORTATION and

FEDERAL HIGHWAY ADMINISTRATION 


\title{
U.S. DEPARTMENT OF THE INTERIOR BRUCE BABBITT, Secretary
}

\author{
U.S. GEOLOGICAL SURVEY \\ Gordon P. Eaton, Director
}

For additional information write to:

District Chief

U.S. Geological Survey 361 Commerce Way

Pembroke, NH 03275-3718
Copies of this report may be purchased from:

U.S. Geological Survey

Branch of Information Services

Open-File Reports Unit

Box 25286

Denver, CO 80225-0286 


\section{CONTENTS}

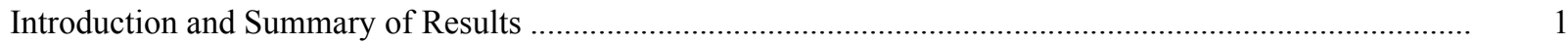

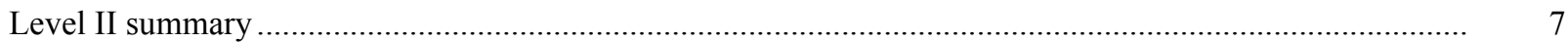

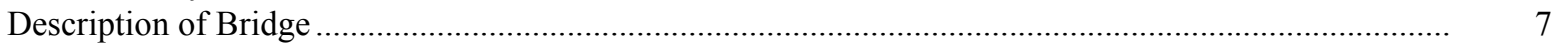

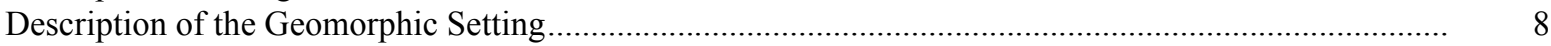

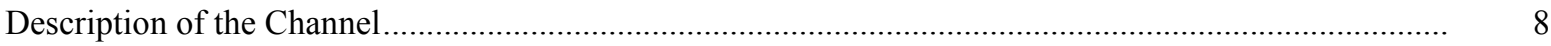

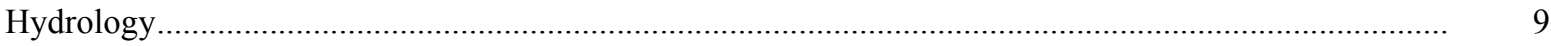

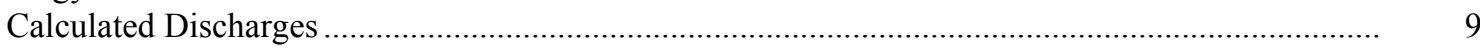

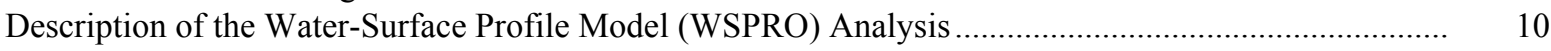

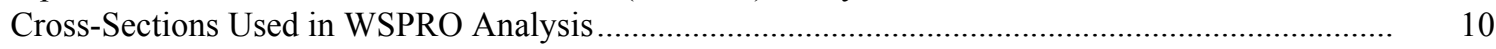

Data and Assumptions Used in WSPRO Model ..................................................................... 11

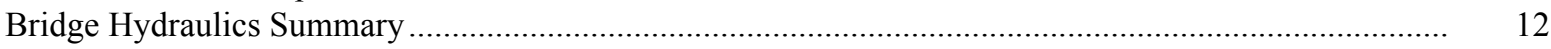

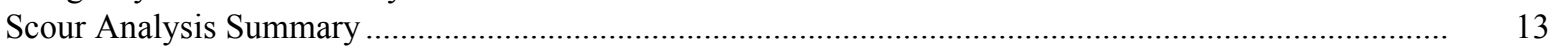

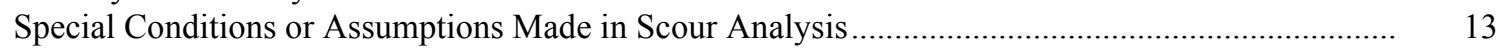

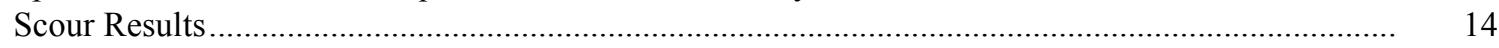

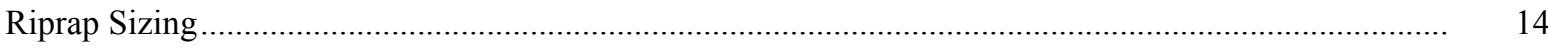

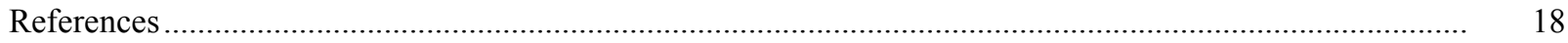

Appendixes:

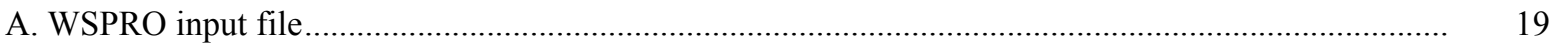

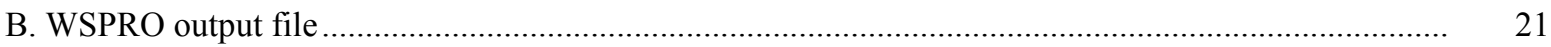

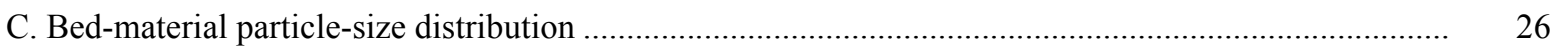

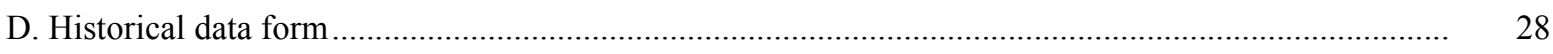

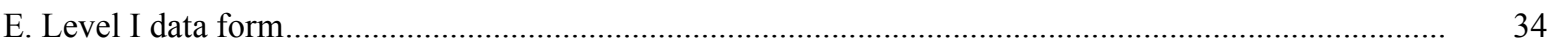

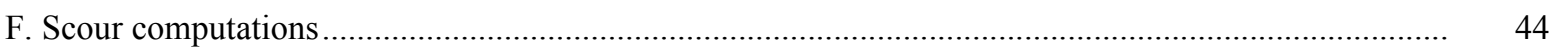

\section{FIGURES}

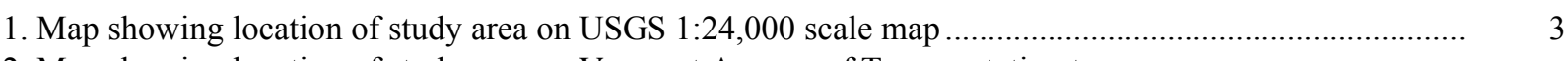

2. Map showing location of study area on Vermont Agency of Transportation town
highway map

3. Structure VICTTH00010006 viewed from upstream (July 20, 1995) ....................................................

4. Downstream channel viewed from structure VICTTH00010006 (July 20, 1995).................................. 5

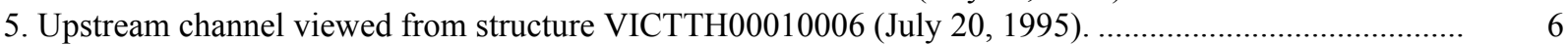

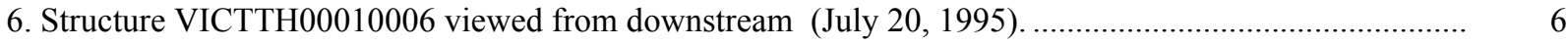

7. Water-surface profiles for the 100- and 500-year discharges at structure

VICTTH00010006 on Town Highway 1, crossing the Moose River,

Victory, Vermont.

8. Scour elevations for the 100- and 500-year discharges at structure

VICTTH00010006 on Town Highway 1, crossing the Moose River,

Victory, Vermont.

\section{TABLES}

1. Remaining footing/pile depth at abutments for the 100-year discharge at structure

VICTTH00010006 on Town Highway 1, crossing the Moose River,

Victory, Vermont

2. Remaining footing/pile depth at abutments for the 500-year discharge at structure

VICTTH00010006 on Town Highway 1, crossing the Moose River,

Victory, Vermont

3
5
5
6
6

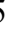




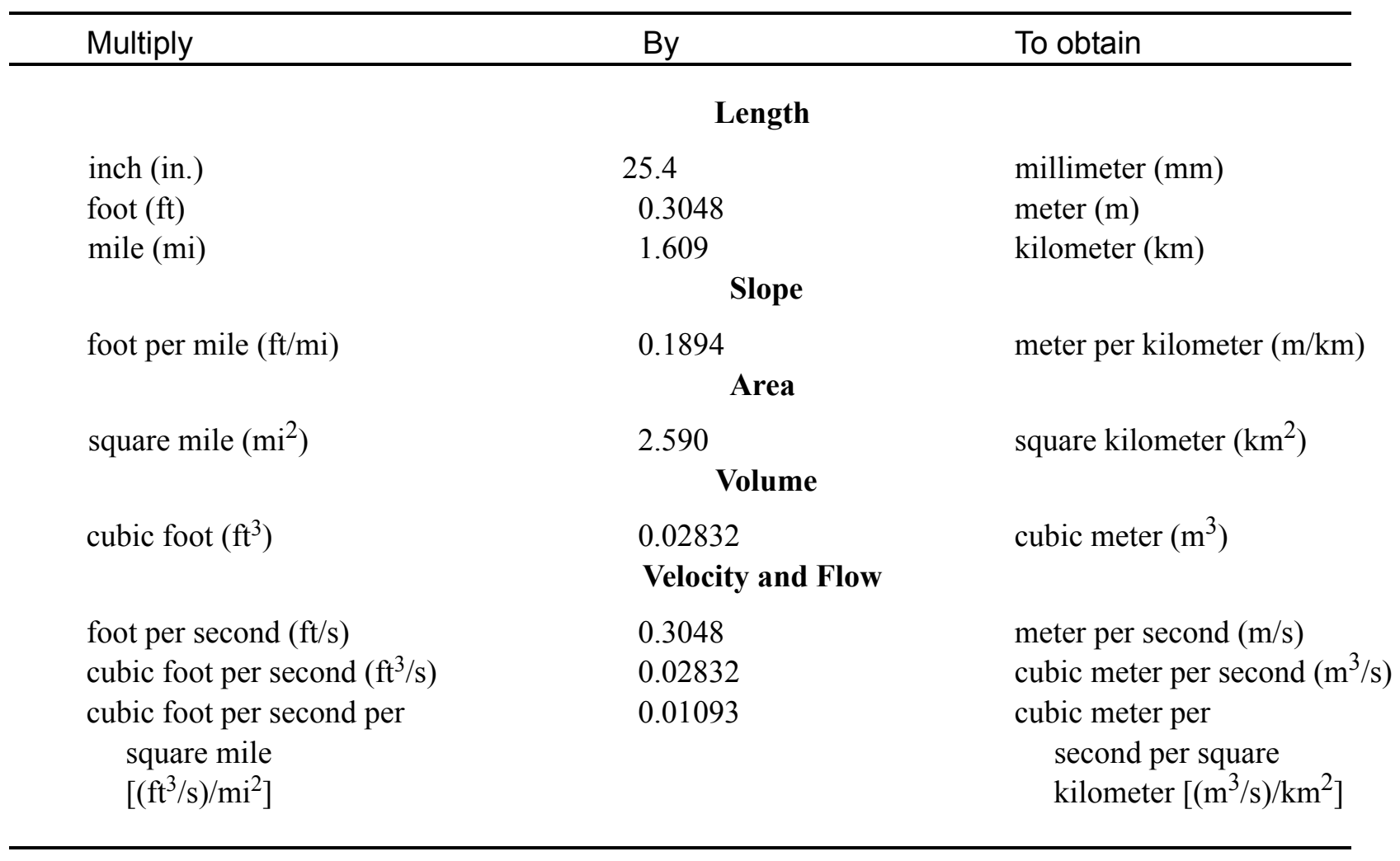

\section{OTHER ABBREVIATIONS}

$\begin{array}{lrlr}\mathrm{BF} & \text { bank full } & \text { LWW } & \text { left wingwall } \\ \mathrm{cfs} & \text { cubic feet per second } & \text { MC } & \text { main channel } \\ \mathrm{D}_{50} & \text { median diameter of bed material } & \text { RAB } & \text { right abutment } \\ \mathrm{DS} & \text { downstream } & \text { RABUT } & \text { face of right abutment } \\ \mathrm{elev} & \text { elevation } & \text { RB } & \text { right bank } \\ \mathrm{f} / \mathrm{p} & \text { flood plain } & \text { ROB } & \text { right overbank } \\ \mathrm{ft}^{2} & \text { square feet } & \text { RWW } & \text { right wingwall } \\ \mathrm{ft} / \mathrm{ft} & \text { feet per foot } & \text { TH } & \text { town highway } \\ \mathrm{JCT} & \text { junction } & \text { UB } & \text { under bridge } \\ \mathrm{LAB} & \text { left abutment } & \text { US } & \text { upstream } \\ \mathrm{LABUT} & \text { face of left abutment } & \text { USGS } & \text { United States Geological Survey } \\ \mathrm{LB} & \text { left bank } & \text { VTAOT Vermont Agency of Transportation } \\ \mathrm{LOB} & \text { left overbank } & \text { WSPRO } & \text { water-surface profile model }\end{array}$

In this report, the words "right" and "left" refer to directions that would be reported by an observer facing downstream. Sea level: In this report, "sea level" refers to the National Geodetic Vertical Datum of 1929-- a geodetic datum derived from a general adjustment of the first-order level nets of the United States and Canada, formerly called Sea Level Datum of 1929.

In the appendices, the above abbreviations may be combined. For example, USLB would represent upstream left bank. 


\title{
LEVEL II SCOUR ANALYSIS FOR BRIDGE 6 (VICTTH00010006) ON TOWN HIGHWAY 1, CROSSING THE MOOSE RIVER, VICTORY, VERMONT
}

\author{
By Scott A. Olson
}

\section{INTRODUCTION AND SUMMARY OF RESULTS}

This report provides the results of a detailed Level II analysis of scour potential at structure VICTTH00010006 on Town Highway 1 crossing the Moose River, Victory, Vermont (figures 1-8). A Level II study is a basic engineering analysis of the site, including a quantitative analysis of stream stability and scour (U.S. Department of Transportation, 1993). Results of a Level I scour investigation also are included in Appendix E of this report. A Level I investigation provides a qualitative geomorphic characterization of the study site. Information on the bridge, gleaned from Vermont Agency of Transportation (VTAOT) files, was compiled prior to conducting Level I and Level II analyses and is found in Appendix D.

The site is in the White Mountain section of the New England physiographic province in northeastern Vermont. The $27.9-\mathrm{mi}^{2}$ drainage area is in a predominantly rural and forested basin. In the vicinity of the study site, the surface cover is forest.

In the study area, the Moose River has an incised, sinuous channel with a slope of approximately $0.02 \mathrm{ft} / \mathrm{ft}$, an average channel top width of $108 \mathrm{ft}$ and an average channel depth of $14 \mathrm{ft}$. The channel bed ranges from gravel to boulder with a median grain size $\left(\mathrm{D}_{50}\right)$ of $126 \mathrm{~mm}(0.412 \mathrm{ft})$. The geomorphic assessment at the time of the Level I and Level II site visit on July 20, 1995, indicated that the reach was stable.

The Town Highway 1 crossing of the Moose River is a 101-ft-long, two-lane bridge consisting of one 98-foot steel-beam span (Vermont Agency of Transportation, written communication, March 28, 1995). The bridge is supported by vertical, concrete abutments with a spill-through slope at the face of each abutment consisting of type- 3 stone fill (less than 48 inches diameter). The channel is skewed approximately 40 degrees to the opening while the opening-skew-to-roadway is 45 degrees.

A scour hole $3 \mathrm{ft}$ deeper than the mean thalweg depth was observed under the bridge during the Level I assessment. Additional details describing conditions at the site are included in the Level II Summary and Appendices D and E. 
Scour depths and rock rip-rap sizes were computed using the general guidelines described in Hydraulic Engineering Circular 18 (Richardson and others, 1995). Total scour at a highway crossing is comprised of three components: 1) long-term streambed degradation; 2) contraction scour (due to accelerated flow caused by a reduction in flow area at a bridge) and; 3) local scour (caused by accelerated flow around piers and abutments). Total scour is the sum of the three components. Equations are available to compute depths for contraction and local scour and a summary of the results of these computations follows.

Contraction scour for all modelled flows ranged from 0.2 to $0.4 \mathrm{ft}$. The worst-case contraction scour occurred at the 500-year discharge. Abutment scour ranged from 7.3 to $8.2 \mathrm{ft}$. The worst-case abutment scour also occurred at the 500-year discharge. Additional information on scour depths and depths to armoring are included in the section titled "Scour Results". Scoured-streambed elevations, based on the calculated scour depths, are presented in tables 1 and 2. A cross-section of the scour computed at the bridge is presented in figure 8. Scour depths were calculated assuming an infinite depth of erosive material and a homogeneous particle-size distribution.

It is generally accepted that the Froehlich equation (abutment scour) gives "excessively conservative estimates of scour depths" (Richardson and others, 1995, p. 47). Usually, computed scour depths are evaluated in combination with other information including (but not limited to) historical performance during flood events, the geomorphic stability assessment, existing scour protection measures, and the results of the hydraulic analyses. Therefore, scour depths adopted by VTAOT may differ from the computed values documented herein. 


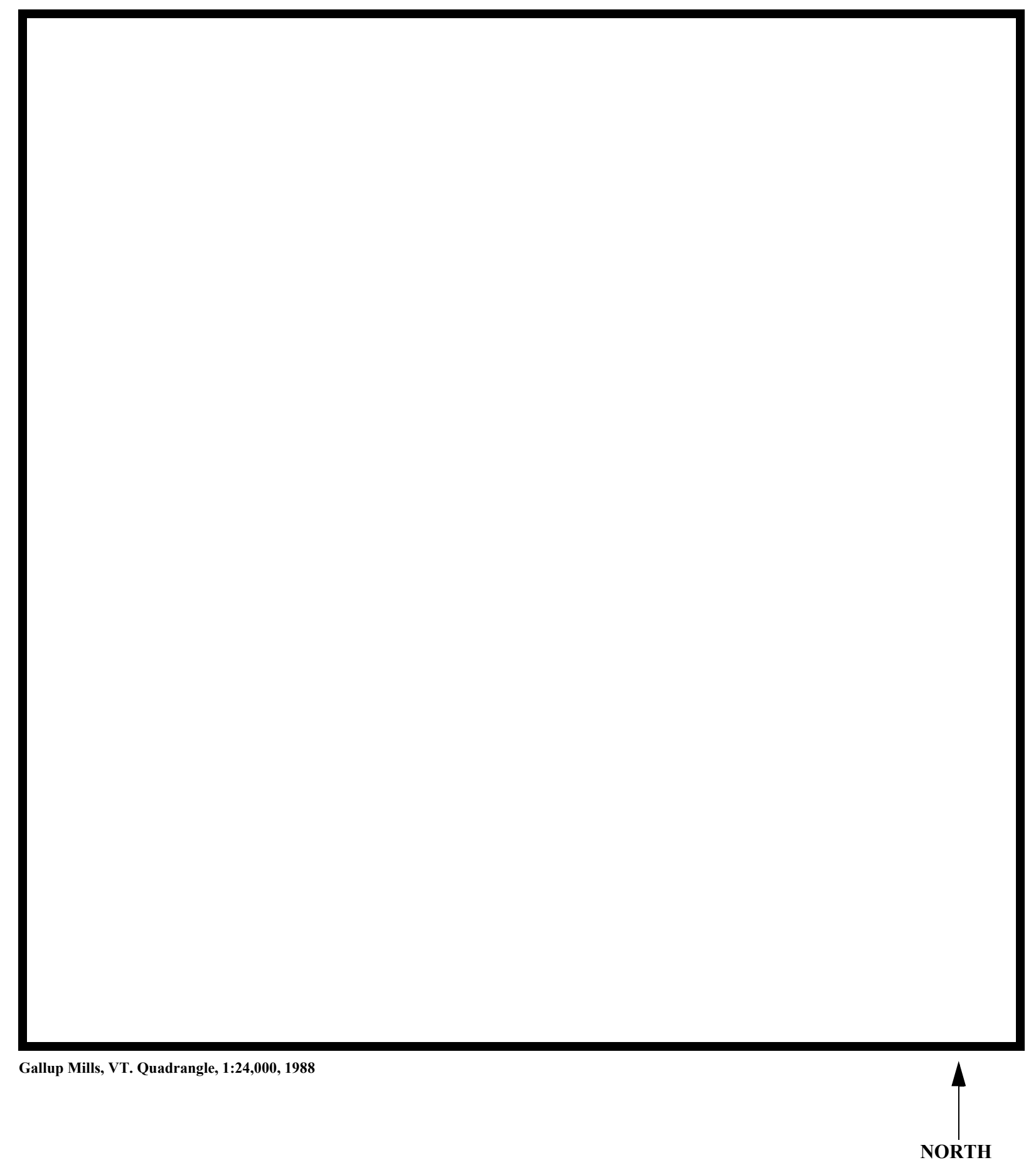

Figure 1. Location of study area on USGS 1:24,000 scale map. 
Figure 2. Location of study area on Vermont Agency of Transportation town highway map. 

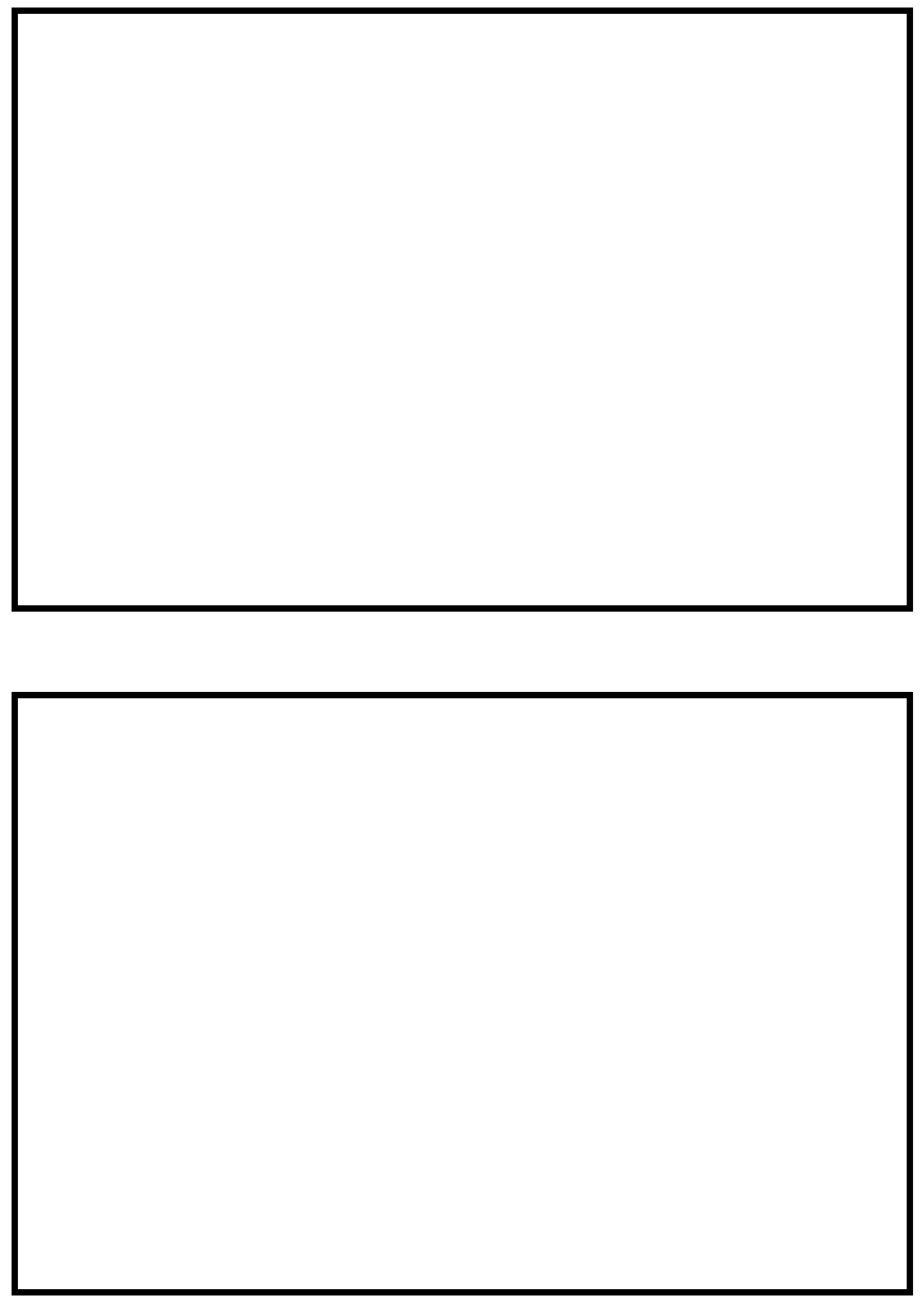

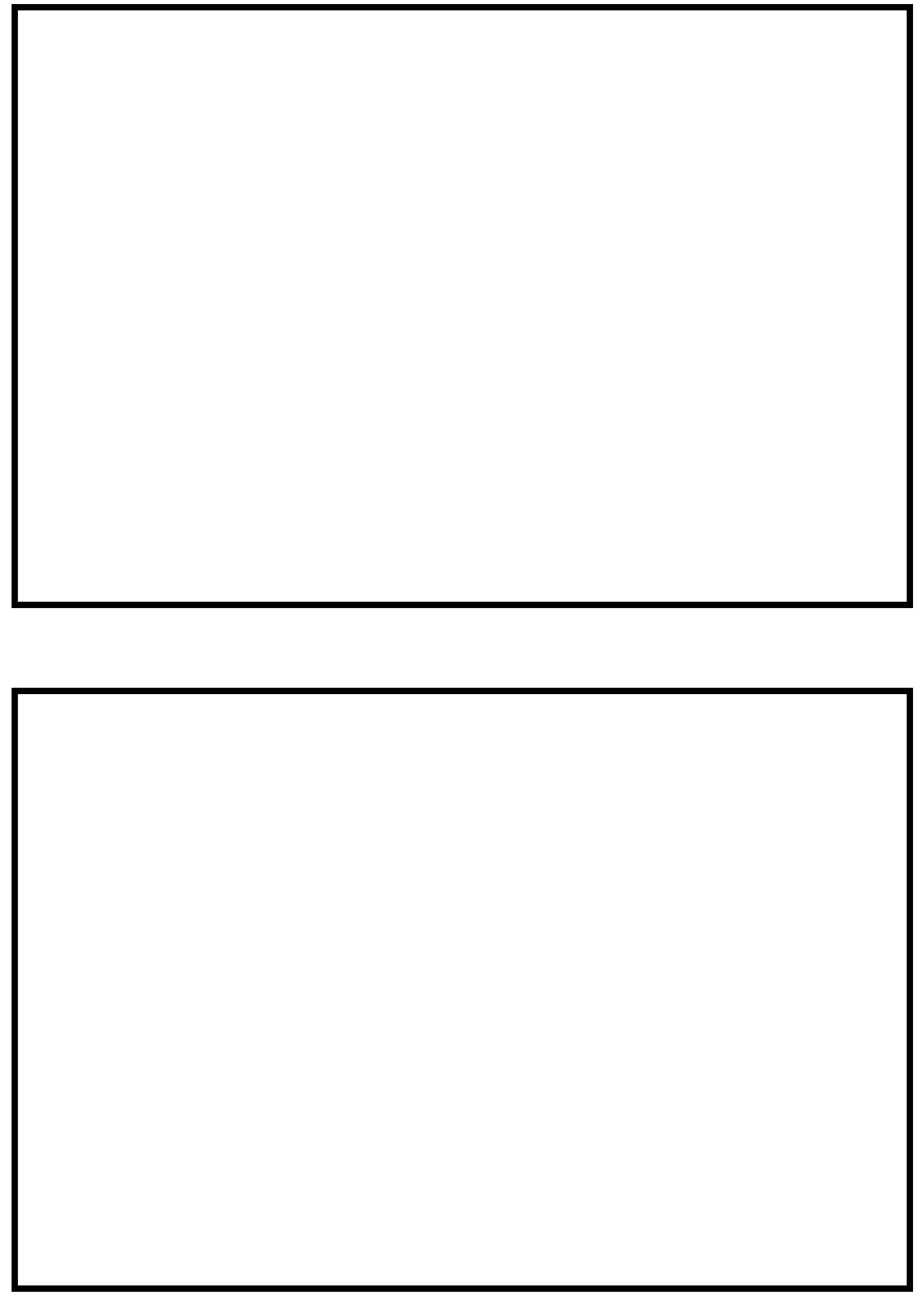


\section{LEVEL II SUMMARY}

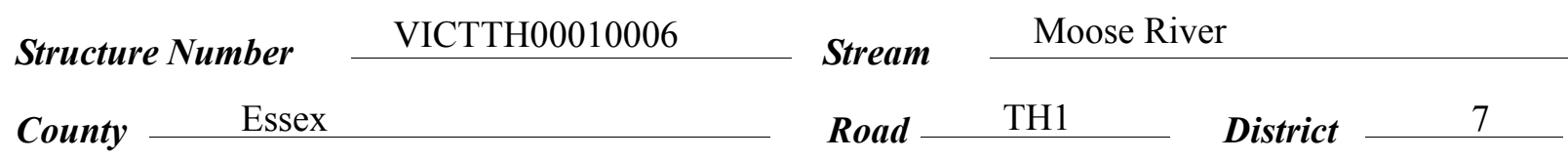

\section{Description of Bridge}

Bridge length $\frac{101}{f t}$ Bridge width $\stackrel{30.8}{f t}$ Max span length $\stackrel{98}{f t}$ Alignment of bridge to road (on curve or straight)

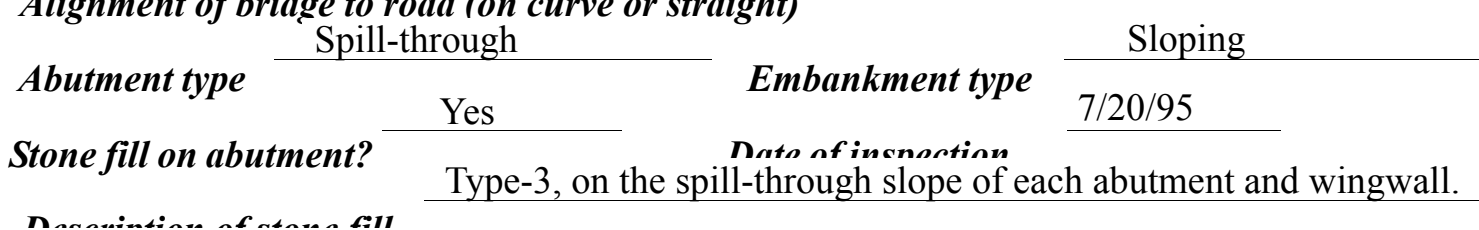

Abutments are spill-through type with the toe of vertical, concrete part of the abutment located at the top of the bank.

- . . . . . . .

Y

40

$\mathrm{N}$

Is bridge skewed to flood flow according to 'survey?

Angle

Debris accumulation on bridge at time of Level I or Level II site visit:

\begin{tabular}{|c|c|c|c|}
\hline & $\begin{array}{c}\text { Date of insnortion } \\
\underline{0}\end{array}$ & $\begin{array}{l}\text { Percent of almmust } \\
\text { blocked inortzontatly }\end{array}$ & $\begin{array}{l}\text { Percent of } 7 / 20 / \\
\text { blocked verticatty }\end{array}$ \\
\hline & 95 & 0 & 0 \\
\hline & Low. & & \\
\hline
\end{tabular}

Potential for debris

Doscriho any, foaturos noar ar at tho hridoo that mav, affort flou, (includo ahsorvation dato) 


\section{Description of the Geomorphic Setting}

General topography The channel is located within a moderate relief valley and has a slope of approximately $0.02 \mathrm{ft} / \mathrm{ft}$.

Geomorphic conditions at bridge site: downstream (DS), upstream (US)

Date of inspection $\quad 7 / 20 / 95$

DS left: $\quad$ Steep channel bank and mildly sloping overbank.

DS right: $\quad$ Steep channel bank and mildly sloping overbank.

US left: $\quad$ Steep channel bank and mildly sloping overbank.

US right: $\quad$ Steep channel bank and mildly sloping overbank.

\section{Description of the Channel}

\begin{tabular}{|c|c|c|c|}
\hline \multirow[b]{2}{*}{ Average top width } & 108 & \multirow[b]{2}{*}{ Average depth } & \multirow[b]{2}{*}{$\begin{array}{c}f t \\
\text { Cobbles }\end{array}$} \\
\hline & $\stackrel{f t}{\boldsymbol{f t}}$ Boulders / Cobbles & & \\
\hline redominant bed $n$ & & Bank material & Straight and stable \\
\hline
\end{tabular}

with non-alluvial channel boundaries and little to no flood plains.

$7 / 20 / 95$

Vegetative co ${ }^{1}$ Forested.

DS left: $\quad$ Forested.

DS right: $\quad$ Forested.

US left: $\quad$ Forested.

US right:

Y

Do banks appear stable? -

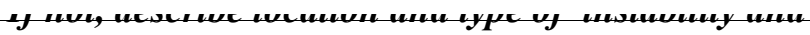

date of observatton.

None, July 20, 1995.

Describe any obstructions in channel and date of observation. 


\title{
Hydrology
}

Drainage area $\stackrel{27.9}{\boldsymbol{m i}^{2}}$

Percentage of drainage area in physiographic provinces: (approximate)

Physiographic province/section

New England/White Mountain
Percent of drainage area 100

\begin{abstract}
Is drainage area considered rural or urban?
Rural None.

urbanization:-

Describe any significant
\end{abstract}

Yes

Is there a USGS gage on the stream of interest?

Moose River at Victory

USGS gage description

01134500

USGS gage number

Gage drainage area $\mathrm{mi}^{\mathbf{7}}$

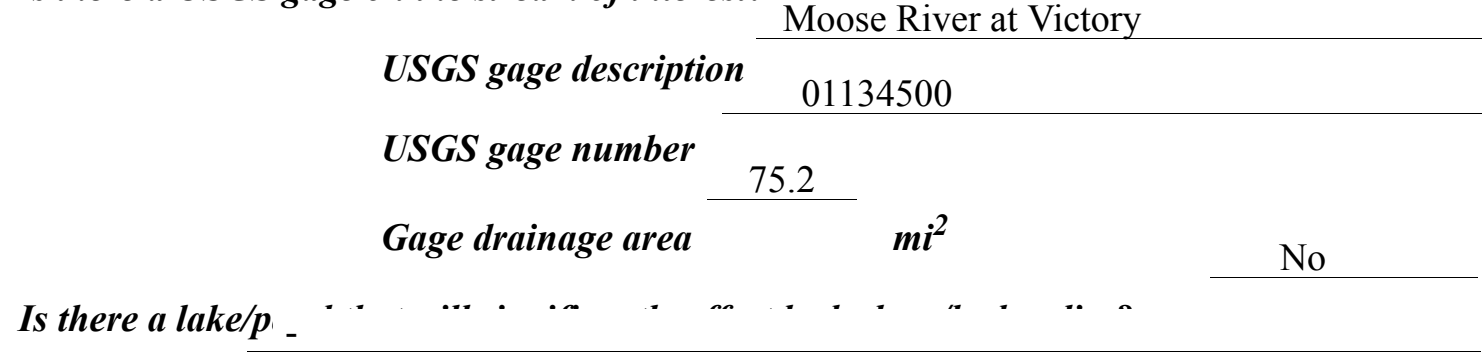

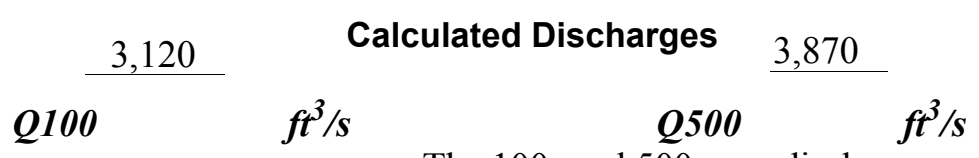

The 100- and 500-year discharges are based on a

drainage area relationship [(27.9/75.2) exp 0.4] with the Moose River gage in Victory. The 100-

and 500-year flood frequency estimates at the gage were made using a Log-Pearson type-3 analysis of the gage data (Interagency Advisory Committee on Water Data, 1982). The final calculated discharges were within a range defined by several empirical methods (Benson, 1962; Johnson and Tasker, 1974; FHWA, 1983; Potter, 1957a\&b; Talbot, 1887). 


\section{Description of the Water-Surface Profile Model (WSPRO) Analysis}

Datum for WSPRO analysis (USGS survey, sea level, VTAOT plans)

USGS survey

Datum tie between USGS survey and VTAOT plans

Add 687.27 feet to arbitrary

survey datum to obtain plans' datum and sea level.

Description of reference marks used to determine USGS datum. $\quad$ RM1 is a chiseled X on

top of the upstream end of the left abutment (elev. $500.20 \mathrm{ft}$, arbitrary survey datum). RM2 is a

chiseled X on top of the downstream end of the right abutment (elev. $499.83 \mathrm{ft}$, arbitrary survey

datum). RM3 is a State of Vermont survey mark, set in the top of the downstream end of the right

abutment (elev. $499.84 \mathrm{ft}$, arbitrary survey datum).

\section{Cross-Sections Used in WSPRO Analysis}

\begin{tabular}{ccll}
\hline${ }^{1}$ Cross-section & $\begin{array}{c}\text { Section } \\
\text { Reference } \\
\text { Distance } \\
\text { (SRD) in feet }\end{array}$ & $\begin{array}{c}{ }^{2} \text { Cross-section } \\
\text { development }\end{array}$ & \multicolumn{1}{c}{ Comments } \\
\hline EXITX & -67 & 1 & $\begin{array}{l}\text { Exit section } \\
\text { Downstream Full-valley } \\
\text { section (Templated from } \\
\text { EXITX) }\end{array}$ \\
BRIDG & 0 & 2 & $\begin{array}{l}\text { Bridge section } \\
\text { Road Grade section }\end{array}$ \\
RDWAY & 0 & 1 & $\begin{array}{l}\text { Modelled Approach sec- } \\
\text { tion (Templated from } \\
\text { APTEM) } \\
\text { APPRO }\end{array}$ \\
APTEM & 114 & 1 & $\begin{array}{l}\text { Approach section as sur- } \\
\text { veyed (Used as a tem- } \\
\text { plate) }\end{array}$ \\
\hline
\end{tabular}

${ }^{1}$ For location of cross-sections see plan-view sketch included with Level I field form, Appendix E. For more detail on how cross-sections were developed see WSPRO input file. 


\section{Data and Assumptions Used in WSPRO Model}

Hydraulic analyses of the reach were done by use of the Federal Highway Administration's WSPRO step-backwater computer program (Shearman and others, 1986, and Shearman, 1990). The analyses reported herein reflect conditions existing at the site at the time of the study. Furthermore, in the development of the model it was necessary to assume no accumulation of debris or ice at the site. Results of the hydraulic model are presented in the Bridge Hydraulic Summary, Appendix B, and figure 7.

Channel roughness factors (Manning's " $n$ ") used in the hydraulic model were estimated using field inspections at each cross section following the general guidelines described by Arcement and Schneider (1989). Final adjustments to the values were made during the modelling of the reach. Channel " $n$ " values for the reach ranged from 0.060 to 0.064 , and overbank " $\mathrm{n}$ " values ranged from 0.090 to 0.110 .

Normal depth at the exit section (EXITX) was assumed as the starting water surface. This depth was computed by use of the slope-conveyance method outlined in the user's manual for WSPRO (Shearman, 1990). The slope used was $0.018 \mathrm{ft} / \mathrm{ft}$ which was estimated from the topographic map (U.S. Geological Survey, 1988).

The surveyed approach section (APTEM) was moved along the approach channel slope $(0.015 \mathrm{ft} / \mathrm{ft})$ to establish the modelled approach section (APPRO), one bridge length upstream of the upstream face as recommended by Shearman and others (1986). This approach also provides a consistent method for determining scour variables.

For the 100- and 500-year discharges, WSPRO assumes critical depth at the bridge section. Supercritical models were developed for these discharges. Analyzing both the supercritical and subcritical profiles for each discharge, it can be determined that the water surface profile does pass through critical depth within the bridge opening. Thus, the assumptions of critical depth at the bridge are satisfactory solutions. 


\section{Bridge Hydraulics Summary}

$\begin{array}{llll}\text { Average bridge embankment elevation } & 500.2 & f t \\ \text { Average low steel elevation } & 494.7 & \boldsymbol{f t}\end{array}$

100-year discharge $\quad 3,120 \quad \mathrm{ft}^{3} / \mathrm{s}$

Water-surface elevation in bridge opening $\quad 488.1 \quad f t$

Road overtopping? ___ N Discharge over road __ _. , s

Area of flow in bridge opening $\quad 250 \quad \mathrm{ft}^{2}$

Average velocity in bridge opening $\quad 12.5 \quad \mathrm{ft} / \mathrm{s}$

$\begin{array}{llll}\text { Maximum WSPRO tube velocity at bridge } & 15.8 \mathrm{ft} / \mathrm{s}\end{array}$

Water-surface elevation at Approach section with bridge 493.6

Water-surface elevation at Approach section without bridge $\quad 489.3$

Amount of backwater caused by bridge

$4.3 \quad i$

500-year discharge $\quad 3,870 \quad \mathrm{ft}^{3} / \mathrm{s}$

Water-surface elevation in bridge opening

$488.9 f t$

Road overtopping? ___ No Discharge over road ___ -- $f t^{3} / \mathrm{s}$

Area of flow in bridge opening $\quad 295 \quad \mathrm{ft}^{2}$

Average velocity in bridge opening $13.1 \mathrm{ft} / \mathrm{s}$

Maximum WSPRO tube velocity at bridge 16.7 's

Water-surface elevation at Approach section with bridge 494.4

Water-surface elevation at Approach section without bridge $\quad 490.0$

Amount of backwater caused by bridge 4.4 ,

Incipient overtopping discharge ___ -- $f t^{3} / \mathrm{s}$

Water-surface elevation in bridge opening $\quad--\quad t$

Area of flow in bridge opening _ -- $\mathrm{ft}^{2}$

Average velocity in bridge opening __- $\quad \mathrm{ft} / \mathrm{s}$

Maximum WSPRO tube velocity at bridge _-- $f t / s$

Water-surface elevation at Approach section with bridge

Water-surface elevation at Approach section without bridge

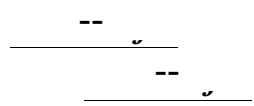

Amount of backwater caused by bridge _ 


\section{Scour Analysis Summary}

\section{Special Conditions or Assumptions Made in Scour Analysis}

Scour depths were computed using the general guidelines described in Hydraulic Engineering Circular 18 (Richardson and others, 1995). Scour depths were calculated assuming an infinite depth of erosive material and a homogeneous particle-size distribution. The results of the scour analysis are presented in tables 1 and 2 and a graph of the scour depths is presented in figure 8.

Contraction scour was computed by use of the clear-water contraction scour equation (Richardson and others, 1995, p. 32, equation 20). The depth to armoring values indicate that armoring will not limit the amount of contraction scour.

Abutment scour was computed by use of the Froehlich equation (Richardson and others, 1995, p. 48, equation 28). Variables for the Froehlich equation include the Froude number of the flow approaching the embankments, the length of the embankment blocking flow, and the depth of flow approaching the embankment less any roadway overtopping.

Because the influence of scour processes on the spill-through embankment material is uncertain, the scour depth at the vertical concrete abutment walls is unknown. Therefore, the total scour depths were applied for the entire spill-through embankment below the elevation at the toe of each embankment, as shown in figure 8 . 


\section{Scour Results}

\section{0-yr discharge 500-yr discharge}

Contraction scour:

(Scour depths in feet)

Main channel

Live-bed scour

Clear-water scour

Depth to armoring

Left overbank

Right overbank

Local scour:

Abutment scour

Left abutment

8.1

8.2

7.3-

$8.0-$

Right abutment

Pier scour

Pier 1

Pier 2

Pier 3

\section{Abutments:}

Left abutment

Right abutment

Piers:

Pier 1

Pier 2

Incipient overtopping discharge 


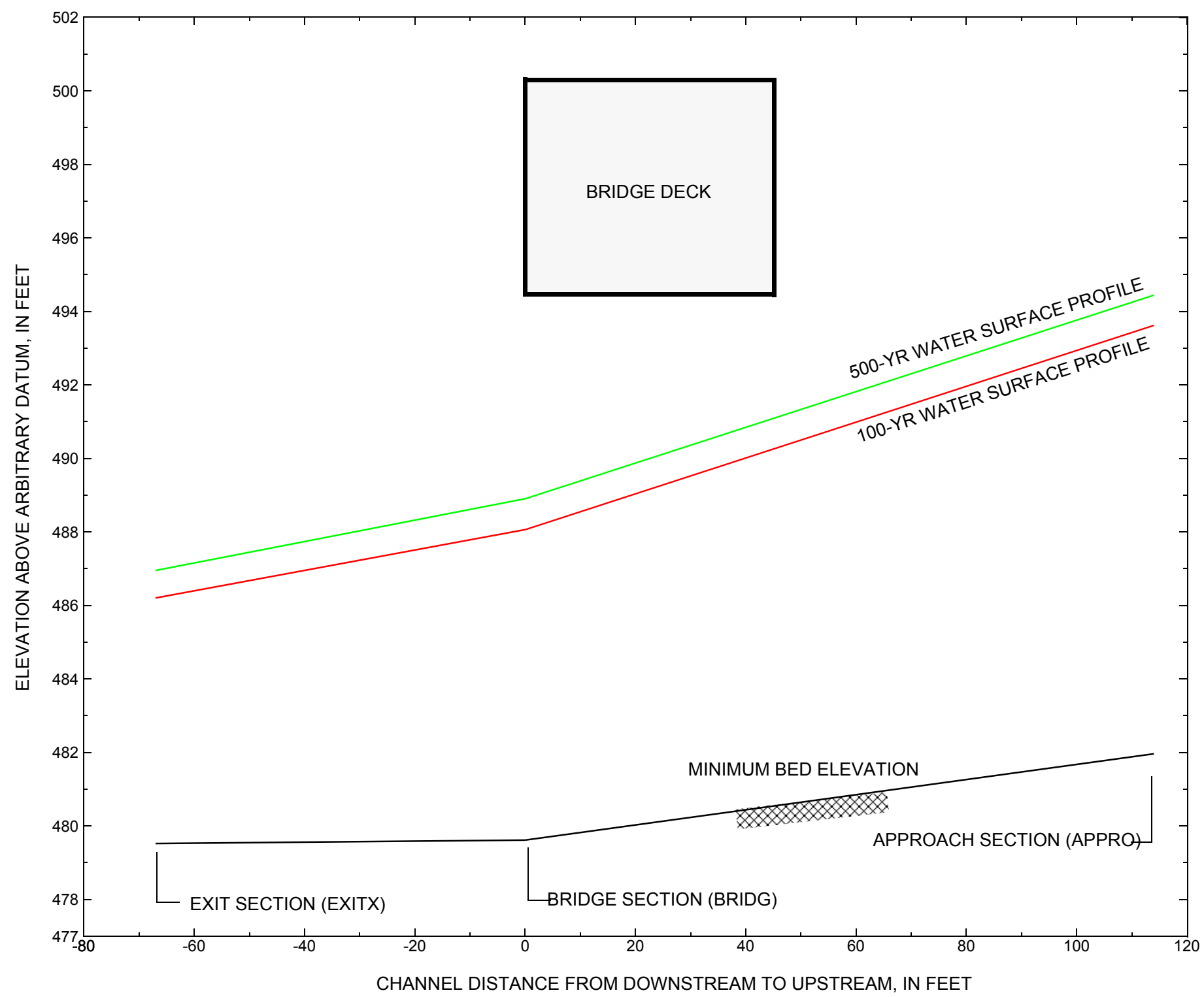

Figure 7. Water-surface profiles for the 100- and 500-yr discharges at structure VICTTH00010006 on Town Highway 1, crossing the Moose River, Victory, Vermont. 


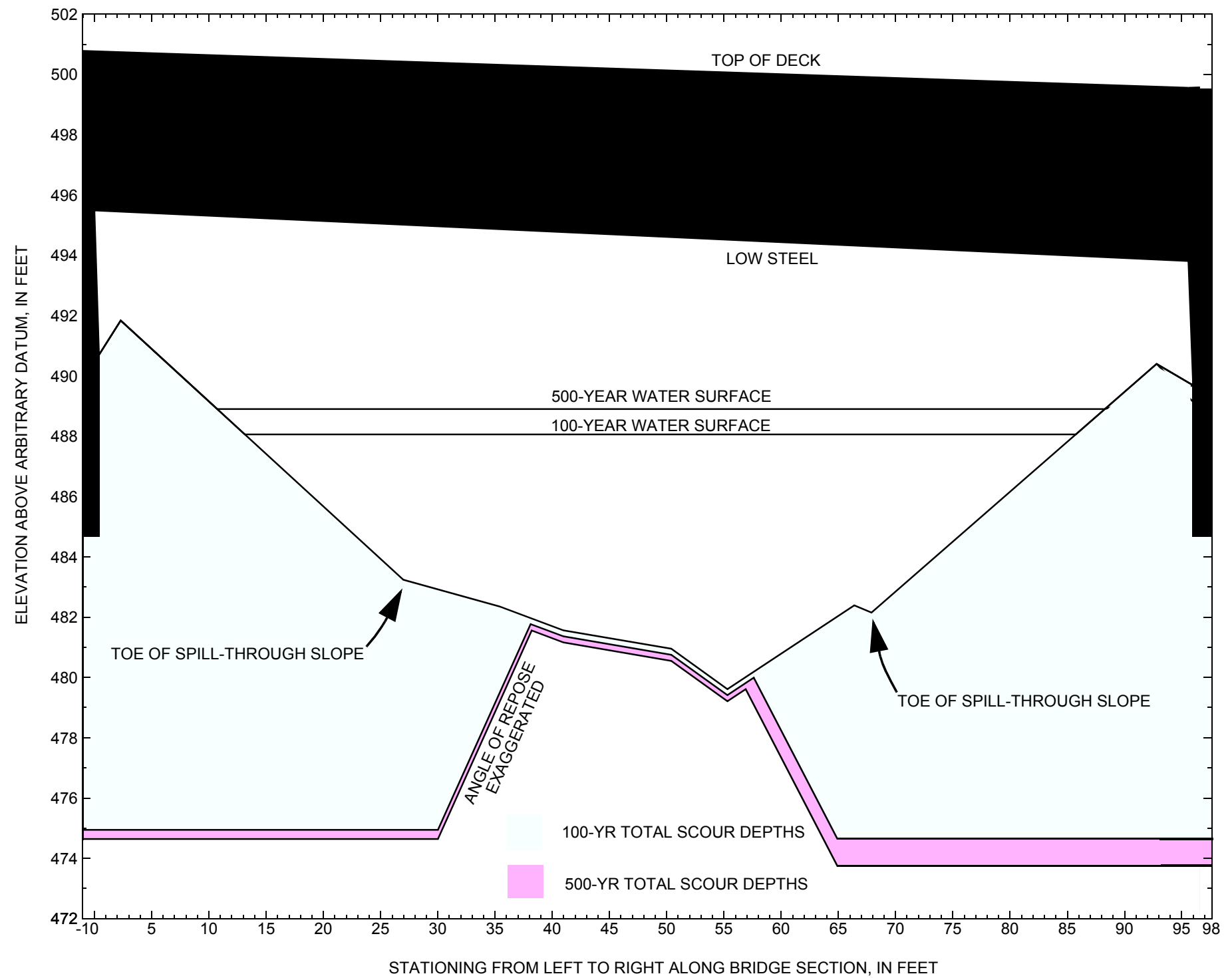

Figure 8. Scour elevations for the 100-yr and 500-yr discharges at structure VICTTH00010006 on Town Highway 1, crossing the Moose River, Victory, Vermont. 
Table 1. Remaining footing/pile depth at abutments for the 100-year discharge at structure VICTTH00010006 on Town Highway 1, crossing the Moose River, Victory, Vermont. [VTAOT, Vermont Agency of Transportation; --,no data]

\begin{tabular}{|c|c|c|c|c|c|c|c|c|c|c|c|}
\hline Description & Station $^{1}$ & $\begin{array}{c}\text { VTAOT } \\
\text { bridge seat } \\
\text { elevation } \\
\text { (feet) }\end{array}$ & $\begin{array}{c}\text { Surveyed } \\
\text { minimum } \\
\text { low-chord } \\
\text { elevation } \\
\text { (feet) }\end{array}$ & $\begin{array}{l}\text { Bottom } \\
\text { of footing } \\
\text { elevation } \\
2 \text { (feet) }\end{array}$ & $\begin{array}{c}\text { Channel } \\
\text { elevation at } \\
\text { abutment/ } \\
\text { pier }^{2} \\
\text { (feet) }\end{array}$ & $\begin{array}{l}\text { Contraction } \\
\text { scour depth } \\
\text { (feet) }\end{array}$ & $\begin{array}{l}\text { Abutment } \\
\text { scour } \\
\text { depth } \\
\text { (feet) }\end{array}$ & $\begin{array}{l}\text { Pier } \\
\text { scour } \\
\text { depth } \\
\text { (feet) }\end{array}$ & $\begin{array}{l}\text { Depth of } \\
\text { total scour } \\
\text { (feet) }\end{array}$ & $\begin{array}{c}\text { Elevation of } \\
\text { scour }^{2} \\
\text { (feet) }\end{array}$ & $\begin{array}{c}\text { Remaining } \\
\text { footing/pile } \\
\text { depth } \\
\text { (feet) }\end{array}$ \\
\hline \multicolumn{12}{|c|}{100 -yr. discharge is 3,120 cubic-feet per second } \\
\hline Left abutment & 0.0 & 1182.4 & 495.5 & 484.7 & 490.7 & -- & -- & -- & -- & -- & -9.8 \\
\hline Left embankment toe & 27.0 & -- & -- & -- & 483.2 & 0.2 & 8.1 & -- & 8.3 & 474.9 & -- \\
\hline Right embankment toe & 67.9 & -- & -- & -- & 482.2 & 0.2 & 7.3 & -- & 7.5 & 474.7 & -- \\
\hline Right abutment & 96.0 & 1181.2 & 493.8 & 484.7 & 489.7 & -- & -- & -- & -- & -- & -10.0 \\
\hline
\end{tabular}

1.Measured along the face of the most constricting side of the bridge.

2.Arbitrary datum for this study.

Table 2. Remaining footing/pile depth at abutments for the 500-year discharge at structure VICTTH00010006 on Town Highway 1, crossing the Moose River, Victory, Vermont. [VTAOT, Vermont Agency of Transportation; --, no data]

\begin{tabular}{|c|c|c|c|c|c|c|c|c|c|c|c|}
\hline Description & Station $^{1}$ & $\begin{array}{l}\text { VTAOT } \\
\text { bridge seat } \\
\text { elevation } \\
\text { (feet) }\end{array}$ & $\begin{array}{l}\text { Surveyed } \\
\text { minimum } \\
\text { low-chord } \\
\text { elevation } \\
\quad \text { (feet) }\end{array}$ & $\begin{array}{l}\text { Bottom of } \\
\text { footing } \\
\text { elevation } \\
\text { (feet) }\end{array}$ & $\begin{array}{c}\text { Channel } \\
\text { elevation at } \\
\text { abutment/ } \\
\text { pier }^{2} \\
\text { (feet) }\end{array}$ & $\begin{array}{l}\text { Contraction } \\
\text { scour depth } \\
\text { (feet) }\end{array}$ & $\begin{array}{l}\text { Abutment } \\
\text { scour } \\
\text { depth } \\
\text { (feet) }\end{array}$ & $\begin{array}{l}\text { Pier } \\
\text { scour } \\
\text { depth } \\
\text { (feet) }\end{array}$ & $\begin{array}{l}\text { Depth of } \\
\text { total scour } \\
\text { (feet) }\end{array}$ & $\begin{array}{c}\text { Elevation of } \\
\text { scour }^{2} \\
\text { (feet) }\end{array}$ & $\begin{array}{c}\text { Remaining } \\
\text { footing/pile } \\
\text { depth } \\
\text { (feet) }\end{array}$ \\
\hline \multicolumn{12}{|c|}{500 -yr. discharge is 3,870 cubic-feet per second } \\
\hline Left abutment & 0.0 & 1182.4 & 495.5 & 484.7 & 490.7 & -- & -- & -- & -- & -- & -10.1 \\
\hline Left embankment toe & 27.0 & -- & -- & -- & 483.2 & 0.4 & 8.2 & -- & 8.6 & 474.6 & -- \\
\hline Right embankment toe & 67.9 & -- & -- & -- & 482.2 & 0.4 & 8.0 & -- & 8.4 & 473.8 & -- \\
\hline Right abutment & 96.0 & 1181.2 & 493.8 & 484.7 & 489.7 & -- & -- & -- & -- & -- & -10.9 \\
\hline
\end{tabular}

1.Measured along the face of the most constricting side of the bridge.

2.Arbitrary datum for this study. 


\section{SELECTED REFERENCES}

Arcement, G.J., Jr., and Schneider, V.R., 1989, Guide for selecting Manning's roughness coefficients for natural channels and flood plains: U.S. Geological Survey Water-Supply Paper 2339, 38 p.

Barnes, H.H., Jr., 1967, Roughness characteristics of natural channels: U.S. Geological Survey Water-Supply Paper 1849,213 p.

Benson, M. A., 1962, Factors Influencing the Occurrence of Floods in a Humid Region of Diverse Terrain: U.S. Geological Survey WaterSupply Paper 1580-B, 64 p.

Brown, S.A. and Clyde, E.S., 1989, Design of riprap revetment: Federal Highway Administration Hydraulic Engineering Circular No. 11, Publication FHWA-IP-89-016, 156 p.

Federal Highway Administration, 1983, Runoff estimates for small watersheds and development of sound design: Federal Highway Administration Report FHWA-RD-77-158

Froehlich, D.C., 1989, Local scour at bridge abutments in Ports, M.A., ed., Hydraulic Engineering--Proceedings of the 1989 National Conference on Hydraulic Engineering: New York, American Society of Civil Engineers, p. 13-18.

Hayes, D.C.,1993, Site selection and collection of bridge-scour data in Delaware, Maryland, and Virginia: U.S. Geological Survey WaterResources Investigation Report 93-4017, 23 p.

Interagency Advisory Committee on Water Data, 1982, Guidelines for determining flood flow frequency: U.S. Geological Survey, Bulletin 17B of the Hydrology Subcommittee, 190 p.

Johnson, C.G. and Tasker, G.D.,1974, Progress report on flood magnitude and frequency of Vermont streams: U.S. Geological Survey OpenFile Report 74-130, 37 p.

Lagasse, P.F., Schall, J.D., Johnson, F., Richardson, E.V., Chang, F., 1995, Stream Stability at Highway Structures: Federal Highway Administration Hydraulic Engineering Circular No. 20, Publication FHWA-IP-90-014, 144 p.

Laursen, E.M., 1960, Scour at bridge crossings: Journal of the Hydraulics Division, American Society of Civil Engineers, v. 86, no. HY2, p. 39-53.

Potter, W. D., 1957a, Peak rates of runoff in the Adirondack, White Mountains, and Maine woods area, Bureau of Public Roads

Potter, W. D., 1957b, Peak rates of runoff in the New England Hill and Lowland area, Bureau of Public Roads

Richardson, E.V. and Davis, S.R., 1995, Evaluating scour at bridges: Federal Highway Administration Hydraulic Engineering Circular No. 18, Publication FHWA-IP-90-017, 204 p.

Richardson, E.V., Simons, D.B., and Julien, P.Y., 1990, Highways in the river environment: Federal Highway Administration Publication FHWA-HI-90-016.

Ritter, D.F., 1984, Process Geomorphology: W.C. Brown Co., Debuque, Iowa, 603 p.

Shearman, J.O., 1990, User's manual for WSPRO--a computer model for water surface profile computations: Federal Highway Administration Publication FHWA-IP-89-027, 187 p.

Shearman, J.O., Kirby, W.H., Schneider, V.R., and Flippo, H.N., 1986, Bridge waterways analysis model; research report: Federal Highway Administration Publication FHWA-RD-86-108, 112 p.

Talbot, A.N., 1887, The determination of water-way for bridges and culverts.

U.S. Department of Transportation, 1993, Stream stability and scour at highway bridges, Participant Workbook: Federal Highway Administration Publication FHWA HI-91-011.

U.S. Geological Survey, 1988, Gallup Mills, Vermont 7.5 Minute Series quadrangle map: U.S. Geological Survey Topographic Maps, Scale $1: 24,000$. 


\section{APPENDIX A: \\ WSPRO INPUT FILE}




\section{WSPRO INPUT FILE}

GR

GR

GR

$\mathrm{N}$

SA

\section{*}

X

BR

GR

GR

GR

GR

CD

$\mathrm{N}$

$\mathrm{XR}$

GR

GR

GR

$X T$

GR

GR

GR

GR

GR

*

AS

GT

$\mathrm{N}$

SA

\section{*}

HP 1 BRIDG

HP 2 BRIDG

$\mathrm{HP} 1 \mathrm{APPRO}$

HP 2 APPRO

*

HP 1 BRIDG

HP 2 BRIDG

$\mathrm{HP} 1 \mathrm{APPRO}$

HP 2 APPRO

EX

ER
U.S. Geological Survey WSPRO Input File vict006.wsp Hydraulic analysis for structure vict006 Date: 04-DEC-96 Hydraulic Analysis of bridge 6 in Victory, VT over Moose River SAO

$\begin{array}{lllllllllllllllllllll}6 & 29 & 30 & 552 & 553 & 551 & 5 & 16 & 17 & 13 & 3 & * & 15 & 14 & 23 & 21 & 11 & 12 & 4 & 7 & 3\end{array}$

31203870

$0.018 \quad 0.018$

$\operatorname{EXITX} \quad-67$

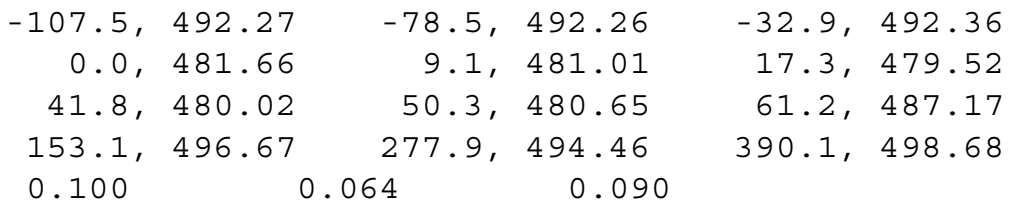

$$
\begin{aligned}
& -32.9
\end{aligned}
$$

$-13.8,485.71$ $27.1,479.92$ $77.9,497.13$
$0.4,490.70$

$41.0,481.56$

$67.9,482.15$

$0.0,495.49$

$96.0,493.81$

$\begin{array}{llll}3 & 46.1 & 5.7 & 500.2\end{array}$

0.060

$$
\begin{array}{r}
23 \\
-475.6 \\
0.0 \\
308.6 \\
\\
137 \\
-444.5 \\
-66.7 \\
14.3 \\
31.9 \\
69.4 \\
\\
114 \\
-0.35 \\
0.110
\end{array}
$$

$$
-475.6,506.85
$$

$0.0,501.16$

$308.6,496.83$

2
-312.8
97.0

$355.7,501.63$
$-192.3,503.90$
$97.0,499.56$
$2.3,491.84$
$50.4,480.95$

$92.8,490.40$

$27.0,483.24$

$55.3,479.61$

$96.0,489.69$$$
-444.5,506.85
$$

$-66.7,501.20$

$-272.0, \quad 505.20$

$-258.1, \quad 504.68$

$-161.7,502.23$

$0.0,491.55$

$9.4,487.72$

$14.3,484.45$

$20.9,484.49$

$26.3,483.60$

$31.9,482.78$

$37.5,482.31$

$42.0,483.21$

$46.0,484.39$

APTEM 137

$69.4,489.11$

$89.0,497.48$

$$
-15.5
$$

0.064

89.0

488.061488 .06

488.06 * 33120

493.621493 .62

$493.62 * \star 3120$

488.901488 .90

488.90 * $* 3870$

494.441494 .44

494.44 * 3870 


\section{APPENDIX B: \\ WSPRO OUTPUT FILE}


WSPRO OUTPUT FILE

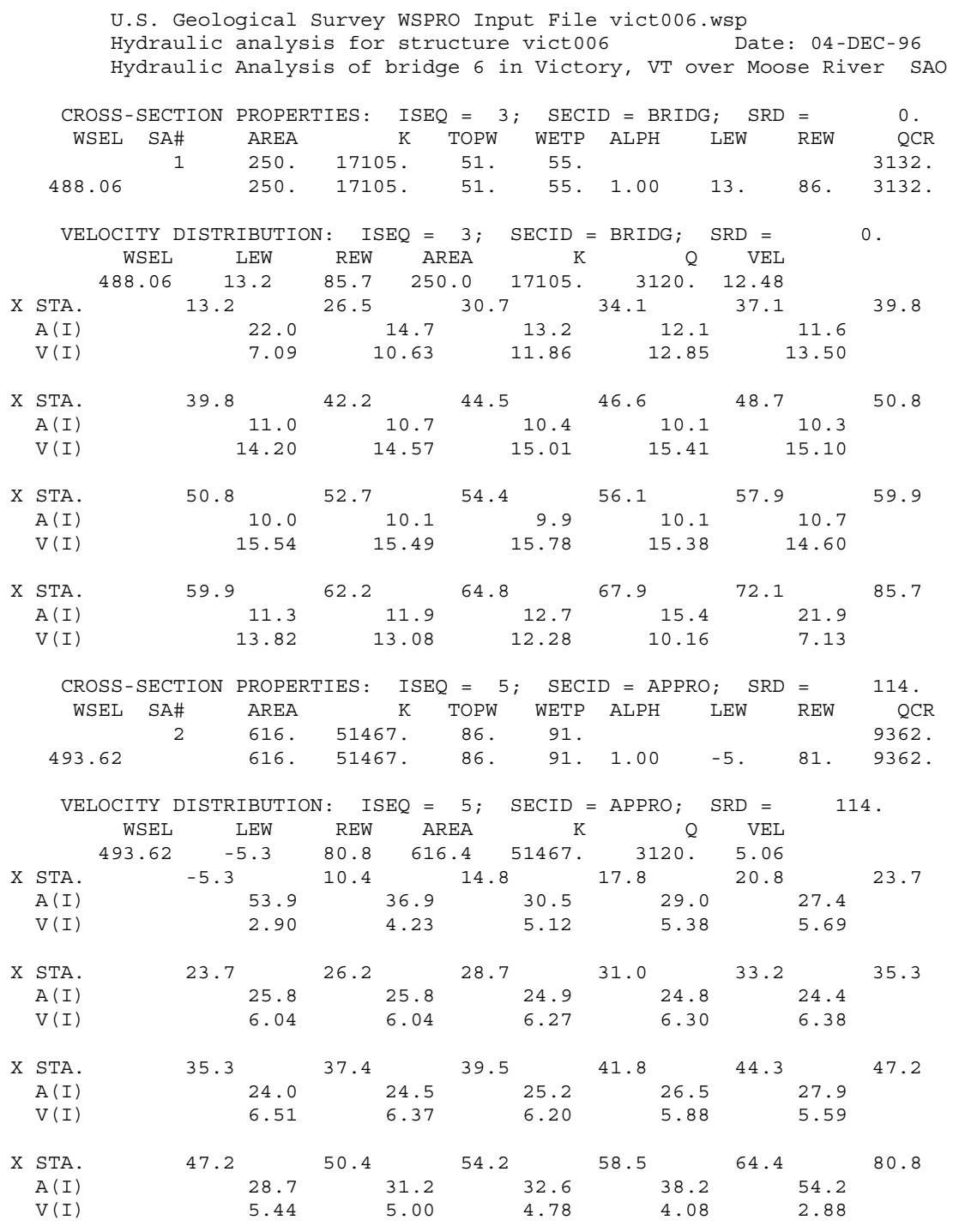


WSPRO OUTPUT FILE (continued)

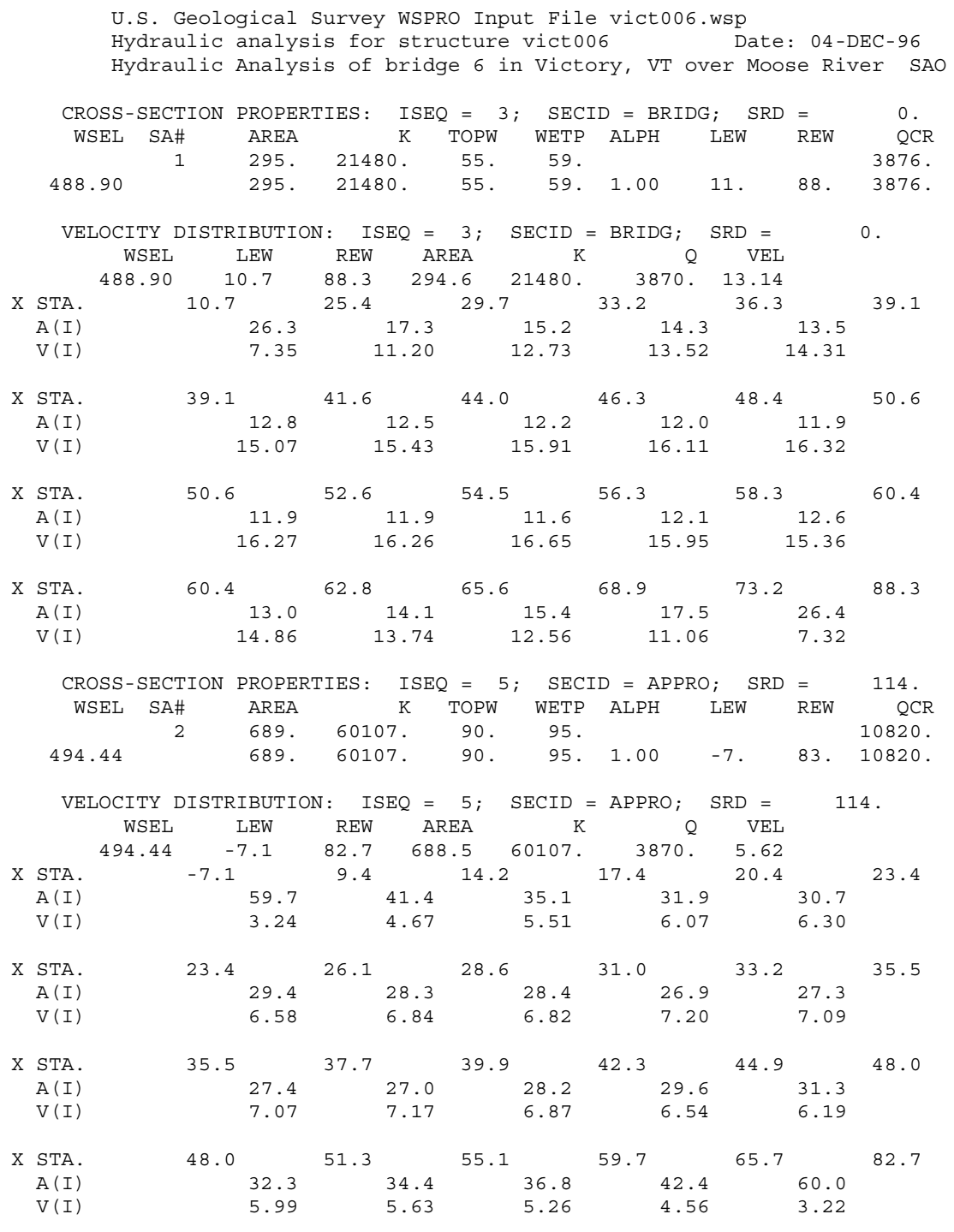


WSPRO OUTPUT FILE (continued)

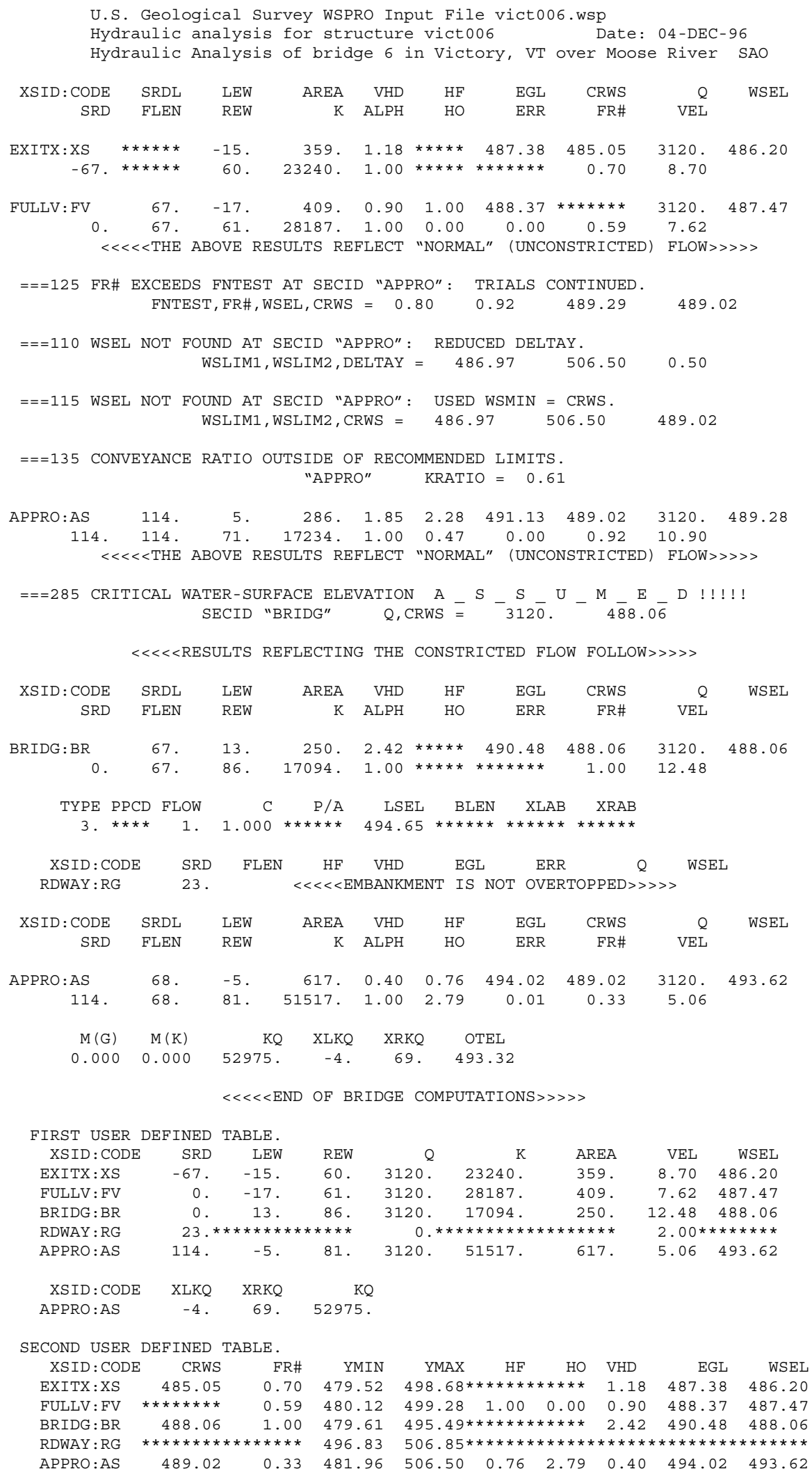


WSPRO OUTPUT FILE (continued)

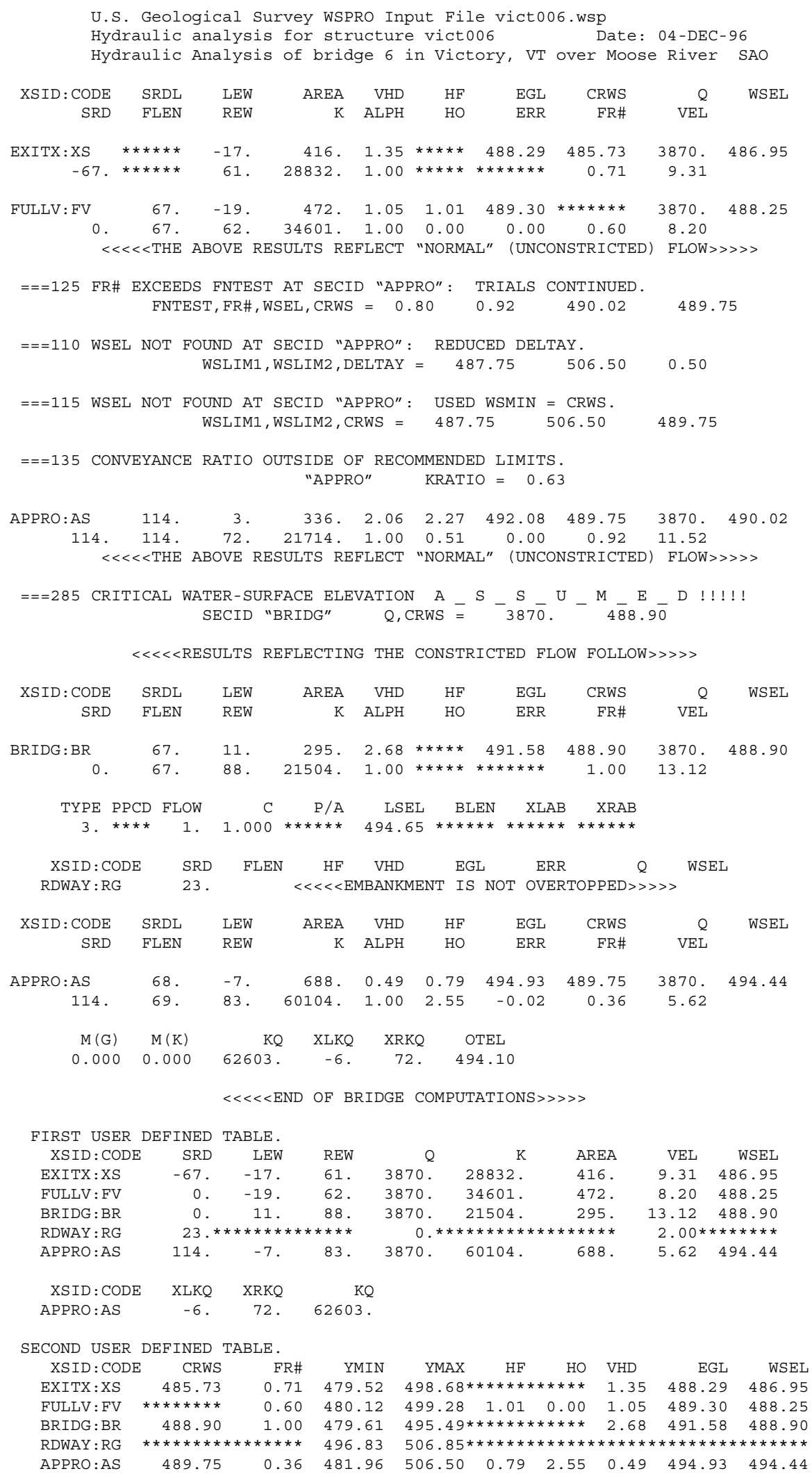




\section{APPENDIX C:}

\section{BED-MATERIAL PARTICAL-SIZE DISTRIBUTION}




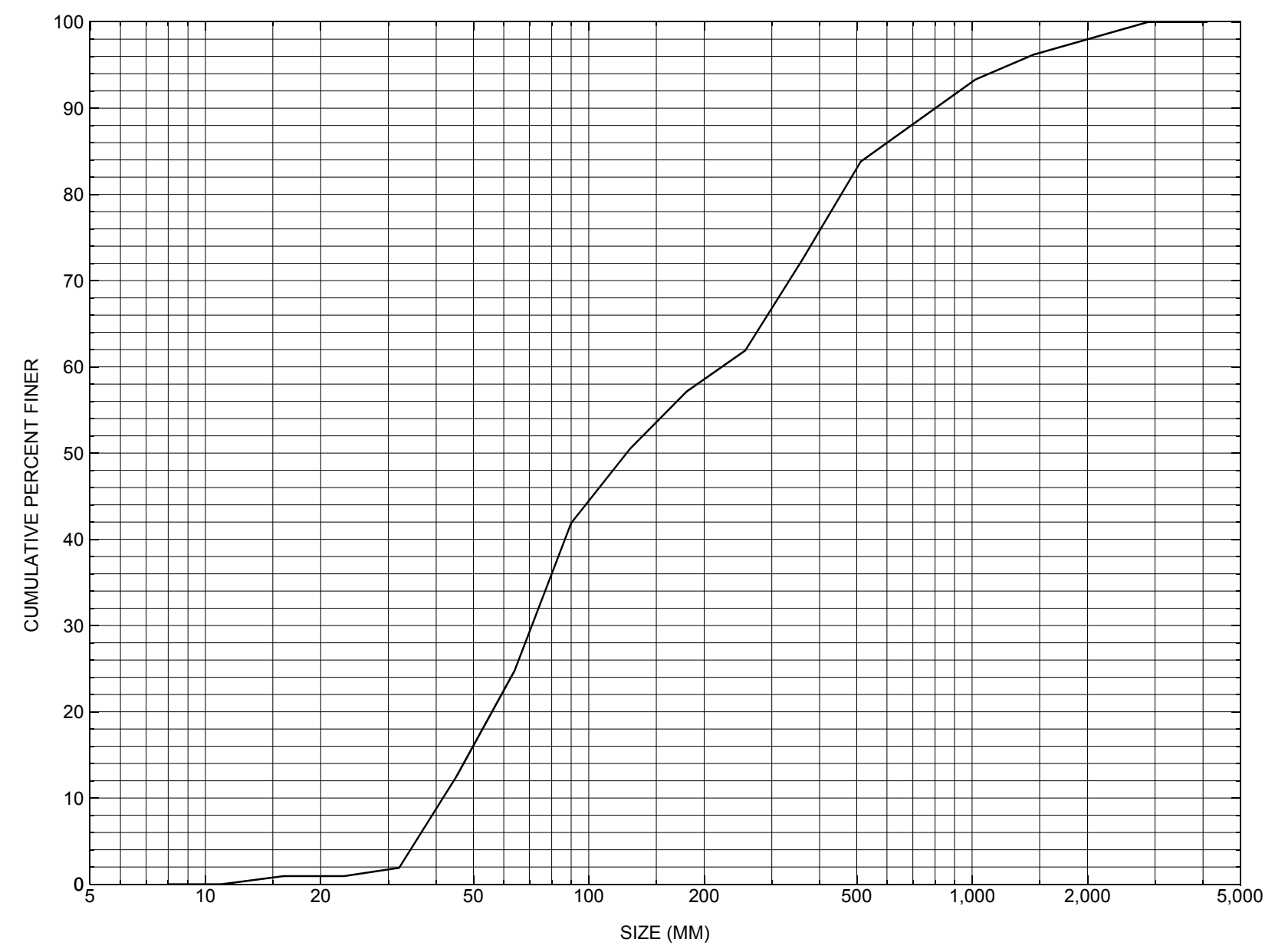

Appendix C. Bed material particle-size distribution for a pebble count in the channel approach of structure VICTTH00010006, in Victory, Vermont. 


\section{APPENDIX D: \\ HISTORICAL DATA FORM}




\section{Structure Number VICTTH00010006}

\section{General Location Descriptive}

Data collected by (First Initial, Full last name) $\underline{\mathbf{E}}$. BOEHMLER

Date $(M M / D D / Y Y) \_\mathbf{0 3} / \underline{\mathbf{2 8}} / \underline{\mathbf{9 5}}$

Highway District Number (I - 2; nn) $\mathbf{0 7}$

Town (FIPS place code; I - 4; nnnnn) $\mathbf{7 5 1 7 5}$

Waterway (I - 6) MOOSE RIVER

Route Number TH001

Topographic Map Gallup.Mills

Latitude (I - 16; nnnn.n) $\mathbf{4 4 3 3 4}$
County (FIPS county code; I - 3; nnn)

Mile marker (I - 11; nnn.nnn) $\underline{\mathbf{0 0 6 0 4 0}}$

Road Name (I - 7): -

Vicinity (I - 9) 8.9 MI N JCT. U.S.2

Hydrologic Unit Code: $\mathbf{0 1 0 8 0 1 0 2}$

Longitude (i - 17; nnnnn.n) 71471

\section{Select Federal Inventory Codes}

FHWA Structure Number (I - 8) $\mathbf{2 0 0 2 7 7 0 0 0 6 0 5 1 7}$

Maintenance responsibility $(I-21 ; n n) \quad \mathbf{0 3}$

Year built (I - 27; YYYY) 1975

Average daily traffic, ADT (I - 29; nnnnnn) 000170

Year of ADT (I - 30; YY) $\mathbf{9 1}$

Opening skew to Roadway (I - 34; nn) 46

Operational status $(I-41 ; X) \quad \mathbf{A}$

Structure type (I - 43; nnn) $\mathbf{3 0 2}$

Approach span structure type $(I-44 ; n n n) \quad \mathbf{0 0 0}$

Number of spans (I - 45; nnn) $\underline{\mathbf{0 0 1}}$

Number of approach spans (I - 46; nnnn) $\mathbf{0 0 0 0}$

Comments:

The structural inspection report of 5/4/94 indicates the structure is a single span, steel stringer type bridge with a concrete deck. This bridge is on the Federal Aid System under the route number, FAS 277. The abutments and wingwalls are concrete, which have hairline shrinkage cracks and some leaks. Both abutments are reported and appear in photographs to be flow through type abutments, with a short section of the concrete abutment walls exposed at the top and the bottoms covered with an earth embankment and protected with heavy stone fill. The river proceeds straight thought the structure. The streambed consists of mainly boulders and gravel. The footings are noted as not in view at the (Continued, page 31) 


\section{Bridge Hydrologic Data}

Is there hydrologic data available? $\underline{\mathbf{Y}}$ if No, type ctrl-n $h \quad$ VTAOT Drainage area $\left(m i^{2}\right): \underline{\mathbf{2 7 . 9}}$

Terrain character: Mountainous

Stream character \& type: -

Streambed material: Gravel with large boulders

Discharge Data (cfs): $\quad \mathrm{Q}_{2.33}$

$$
\mathrm{Q}_{50} \mathbf{4 8 0 0}
$$

$\mathrm{Q}_{10} \frac{\mathbf{3 0 0 0}}{\mathrm{Q}_{100}-}$

$\mathrm{Q}_{25}$

$\mathrm{Q}_{500}$

Record flood date $(M M / D D / Y Y)$ :

Water surface elevation (ft): -

Estimated Discharge (cfs): I $(f t / s):$

Ice conditions (Heavy, Moderate, Light): Moderate Debris (Heavy, Moderate, Light): Moderate

The stage increases to maximum highwater elevation (Rapidly, Not rapidly): Rapidly

The stream response is (Flashy, Not flashy):

Flashy

Describe any significant site conditions upstream or downstream that may influence the stream's stage: Possible backwater from victory dam reservoir, if it is ever built.

Watershed storage area (in percent):

The watershed storage area is: - (1-mainly at the headwaters; 2- uniformly distributed; 3-immediatly upstream oi the site)

Water Surface Elevation Estimates for Existing Structure:

\begin{tabular}{|l|l|l|l|l|l|}
\hline Peak discharge frequency & $Q_{2.33}$ & $Q_{10}$ & $Q_{25}$ & $Q_{50}$ & $Q_{100}$ \\
Water surface elevation (ft)) & - & - & $\mathbf{1 1 7 8 . 5}$ & - & - \\
Velocity $(\mathrm{ft} / \mathrm{sec})$ & - & - & $\mathbf{1 2 . 7}$ & - & - \\
\hline
\end{tabular}

Long term stream bed changes: -

Is the roadway overtopped below the $\mathrm{Q}_{100}$ ? (Yes, No, Unknown): $\mathbf{N} \quad$ Frequency: -

Relief Elevation $(f t)$ :

Discharge over roadway at $\mathrm{Q}_{100}\left(\mathrm{ft}^{3} / \mathrm{sec}\right)$ :

Are there other structures nearby? (Yes, No, Unknown): Y Upstream distance (miles): Town: If No or Unknown, type ctrl-n os Highway No. : TH02 Structure No. : 04 Year Built:

Clear span (ft): $\underline{\mathbf{4 0 . 0}}$ Clear Height $(f t): \underline{\mathbf{1 2 . 0}}$ Full Waterway $\left(f t^{2}\right): \underline{\mathbf{4 8 0 . 0}}$ 
Downstream distance (miles): Town:

Concord

Year Built:

Highway No. : TH01 Structure No. : 37 Structure Type:

Clear span (ft): $\underline{\mathbf{7 0 . 0}}$ Clear Height $(f t): \underline{\mathbf{1 1 . 0}}$ Full Waterway $\left(\mathrm{ft}^{2}\right): \mathbf{7 7 0 . 0}$

Comments:

surface and there has been no settling reported. There has been no channel scour noted. The bridge is in good condition.

\section{USGS Watershed Data}

Watershed Hydrographic Data

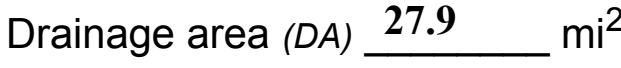

Lake and pond area $\mathbf{0 . 2 1}$ $\mathrm{mi}^{2}$

Watershed storage (ST) 0.7

Bridge site elevation 1186 $\mathrm{ft}$ $\%$

Main channel length $\mathbf{1 2 . 7 7}$ $\mathrm{mi}$

$10 \%$ channel length elevation 1265 $\mathrm{ft} \quad 85 \%$ channel length elevation $\mathrm{ft}$

Main channel slope $(S)$ 117.07 $\mathrm{ft} / \mathrm{mi}$

Watershed Precipitation Data

Average site precipitation in

Average headwater precipitation in

Maximum 2yr-24hr precipitation event $(124,2)$ in

Average seasonal snowfall (Sn) $\mathrm{ft}$ 


\section{Bridge Plan Data}

Are plans available? $\mathbf{Y}$ If no, type ctrl-n pl Date issued for construction (MM/YYYY): 04 / 1974 Project Number RS 0277(1) SA

Low superstructure elevation: USLAB $\underline{\mathbf{1 1 8 2 . 4 4}}$ DSLAB $\underline{\mathbf{1 1 8 3 . 4 1}}$ USRAB $\underline{\mathbf{1 1 8 1 . 2 1}}$ DSRAB $\underline{\mathbf{1 1 8 2 . 2 3}}$ Benchmark location description:

State of Vermont survey mark, set in top of concrete at downstream end of the right abutment, elevation 1187.11 feet

Reference Point (MSL, Arbitrary, Other): MSL Datum (NAD27, NAD83, Other): NGVD 1929 Foundation Type: 1

If 1: Footing Thickness $2 \mathbf{2 . 0} \quad$ Footing bottom elevation: $\underline{\mathbf{1 1 7 2 . 0}}$

If 2: Pile Type:___ (1-Wood; 2-Steel or metal; 3-Concrete) Approximate pile driven length:

If 3: Footing bottom elevation:

Is boring information available? $\underline{\mathbf{Y}}$ If no, type ctrl- $n$ bi Number of borings taken: $\underline{\mathbf{2}}$

Foundation Material Type: 1 (1-regolith, 2-bedrock, 3-unknown)

Briefly describe material at foundation bottom elevation or around piles:

The abutment footings are set in a sand, silt, and stone material.

Comments:

Other points shown on the plans with elevations are: 1) the point on the top streamward edge of the upstream right wingwall concrete where the concrete slope changes from horizontal to downward, elevation 1186.23, and 2) the point at the same location, but on the upstream left wingwall, elevation 1187.46. 


\section{Cross-sectional Data}

Is cross-sectional data available? $\underline{\mathbf{Y}}$

If no, type ctrl-n xs

Source (FEMA, VTAOT, Other)? VTAOT

Comments: Orientation of the cross sections is inconsistent with any cross section data surveyed for this study and is not comparable. Data was not retrieved.

\begin{tabular}{|c|c|c|c|c|c|c|c|c|c|c|c|}
\hline Station & -- & -- & -- & -- & -- & -- & -- & -- & -- & -- & -- \\
\hline Feature & -- & -- & -- & -- & -- & -- & -- & -- & -- & -- & -- \\
\hline $\begin{array}{l}\text { Low cord } \\
\text { elevation }\end{array}$ & -- & -- & -- & -- & -- & -- & -- & -- & -- & -- & -- \\
\hline $\begin{array}{l}\text { Bed } \\
\text { elevation }\end{array}$ & -- & -- & -- & -- & -- & -- & -- & -- & -- & -- & -- \\
\hline $\begin{array}{l}\text { Low cord to } \\
\text { bed length }\end{array}$ & -- & -- & -- & -- & -- & -- & -- & -- & -- & -- & -- \\
\hline Station & -- & -- & -- & -- & -- & -- & -- & -- & -- & -- & -- \\
\hline Feature & -- & -- & -- & -- & -- & - & -- & -- & -- & -- & -- \\
\hline $\begin{array}{l}\text { Low cord } \\
\text { elevation }\end{array}$ & -- & -- & -- & -- & -- & -- & -- & -- & -- & -- & -- \\
\hline $\begin{array}{l}\text { Bed } \\
\text { elevation }\end{array}$ & -- & -- & -- & -- & -- & -- & -- & -- & -- & -- & -- \\
\hline $\begin{array}{l}\text { Low cord to } \\
\text { bed length }\end{array}$ & -- & -- & -- & -- & -- & -- & -- & -- & -- & -- & -- \\
\hline
\end{tabular}

Source (FEMA, VTAOT, Other)?

Comments: --

\begin{tabular}{|c|c|c|c|c|c|c|c|c|c|c|c|}
\hline Station & -- & -- & -- & -- & -- & -- & -- & -- & -- & - & - \\
\hline Feature & -- & -- & -- & - & -- & -- & -- & - & - & - & - \\
\hline $\begin{array}{l}\text { Low cord } \\
\text { elevation }\end{array}$ & -- & -- & - & - & -- & -- & -- & - & -- & -- & -- \\
\hline $\begin{array}{l}\text { Bed } \\
\text { elevation }\end{array}$ & -- & -- & -- & - & -- & -- & -- & -- & -- & -- & -- \\
\hline $\begin{array}{l}\text { Low cord to } \\
\text { bed length }\end{array}$ & -- & -- & -- & - & -- & -- & -- & -- & -- & -- & -- \\
\hline Station & -- & -- & -- & -- & -- & -- & -- & - & - & - & - \\
\hline Feature & -- & -- & -- & - & -- & -- & -- & - & - & -- & -- \\
\hline $\begin{array}{l}\text { Low cord } \\
\text { elevation }\end{array}$ & -- & -- & -- & - & - & -- & -- & -- & -- & -- & -- \\
\hline $\begin{array}{l}\text { Bed } \\
\text { elevation }\end{array}$ & -- & -- & -- & - & -- & -- & -- & -- & -- & -- & -- \\
\hline $\begin{array}{l}\text { Low cord to } \\
\text { bed length }\end{array}$ & -- & -- & -- & - & -- & -- & |-- & -- & -- & -- & -- \\
\hline
\end{tabular}




\section{APPENDIX E: \\ LEVEL I DATA FORM}


U. S. Geological Survey

Bridge Field Data Collection and Processing Form

Qa/Qc Check by: EW Date: $\underline{\mathbf{0 4} / 03 / 96}$

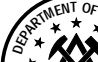

\section{Structure Number VICTTH00010006} Computerized by: $\underline{\mathbf{E W} \text { Date: } 04 / 04 / 96}$

Reviewd by: SAO Date: $\underline{\mathbf{1 2} / \mathbf{1 0} / 96}$

\section{A. General Location Descriptive}

1. Data collected by (First Initial, Full last name) $\mathbf{R}$. HAMMOND

Date $(M M / D D / Y Y) \underline{\mathbf{0 7}} / \underline{\mathbf{2 0} / 1995}$

2. Highway District Number $\mathbf{0 7}$

County 009

Waterway (I - 6) MOOSE RIVER

Route Number TH001

3. Descriptive comments:

8.9 MILES NORTH OF JUNCTION WITH US 2.

Federal Aid System Bridge (\#277).
Mile marker 066040

Town VICTORY $\mathbf{7 5 1 7 5}$

Road Name -

Hydrologic Unit Code: $\mathbf{0 1 0 8 0 1 0 2}$

\section{B. Bridge Deck Observations}
4. Surface cover... LBUS 6
RBUS 6
LBDS 6
RBDS 6
Overall 6

(2b us,ds,lb,rb: 1- Urban; 2- Suburban; 3- Row crops; 4- Pasture; 5- Shrub- and brushland; 6- Forest; 7- Wetland)
5. Ambient water surface... US $\underline{2}$
UB 2
DS $\underline{2}$
(1- pool; 2- riffle)

6. Bridge structure type 1 (1- single span; 2- multiple span; 3- single arch; 4- multiple arch; 5-cylindrical culvert; 6- box culvert; or 7- other)
7. Bridge length 101
(feet)
Span length 98
(feet)
Bridge width $\underline{\mathbf{3 0 . 8}}$ (feet)

\section{Road approach to bridge:}
8. LB 2
RB 2
( 0 even, 1- lower, 2- higher)
9. LB
RB $\underline{2}$
(1- Paved, 2- Not paved)

10. Embankment slope (run / rise in feet / foot):

$$
\text { US left }
$$

3.1:1

US right

8.4:1

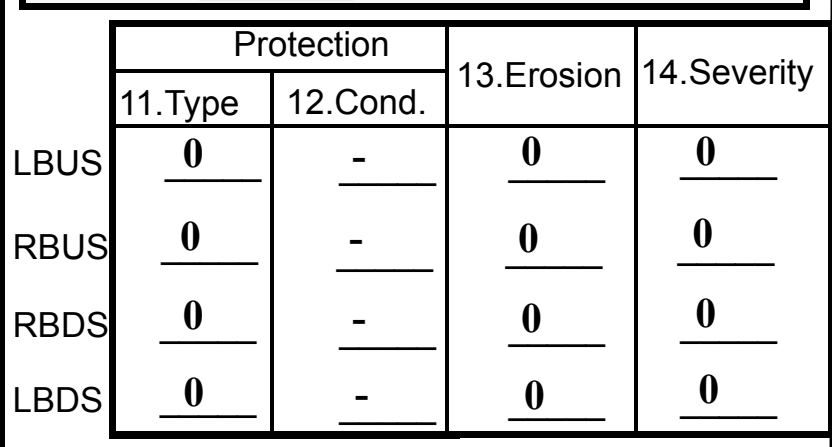

Bank protection types: 0 - none; 1- $<12$ inches;

$$
\text { 2- < } 36 \text { inches; } 3 \text { - < } 48 \text { inches; }
$$

4- < 60 inches; 5- wall / artificial levee

Bank protection conditions: 1- good; 2- slumped;

3- eroded; 4- failed

Erosion: 0 - none; 1- channel erosion; 2-

road wash; 3- both; 4- other

Erosion Severity: 0 - none; 1- slight; 2- moderate; 3- severe

\section{Channel approach to bridge (BF):}

15. Angle of approach: $\mathbf{0}$

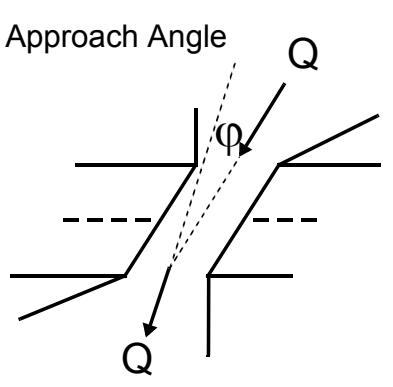

17. Channel impact zone 1 :

Where? LB (LB, RB)

Range? 20 feet DS

Channel impact zone 2:

Where? $(L B, R B)$

Range? feet (US, UB, DS) to feet

16. Bridge skew: $\mathbf{4 0}$ Bridge Skew Angle

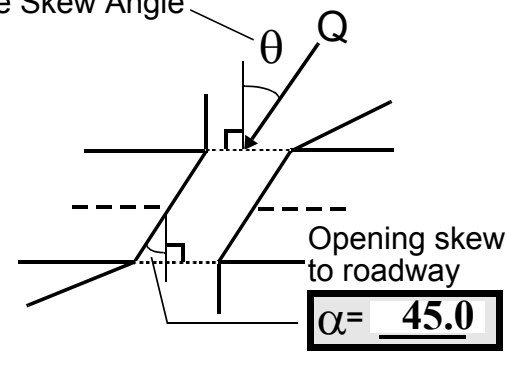

\section{Exist? $\mathbf{Y}(Y$ or $N)$}

Severity 1

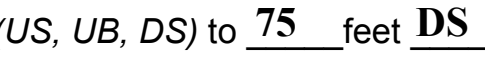

Exist? $\underline{\mathbf{N}}(\mathrm{Y}$ or $N)$

Severity

Impact Severity: 0- none to very slight; 1- Slight; 2- Moderate; 3- Severe 
18. Bridge Type: $\underline{\mathbf{1 a} / \mathbf{3}}$

1a- Vertical abutments with wingwalls

1 b- Vertical abutments without wingwalls

2- Vertical abutments and wingwalls, sloping embankment

Wingwalls perpendicular to abut. face

3- Spill through abutments

4- Sloping embankment, vertical wingwalls and abutments

1a with wingwalls

Wingwall angle less than $90^{\circ}$.

19. Bridge Deck Comments (surface cover variations, measured bridge and span lengths, bridge type variations,

approach overflow width, etc.)

\#4: LBUS and RBDS surface cover includes road TH 1.

\#8: Road is slightly higher than bridge.

\#18: The bridge has spill-through type abutments with wingwalls. The spill-through slope extends up wingwalls.

\section{Upstream Channel Assessment}

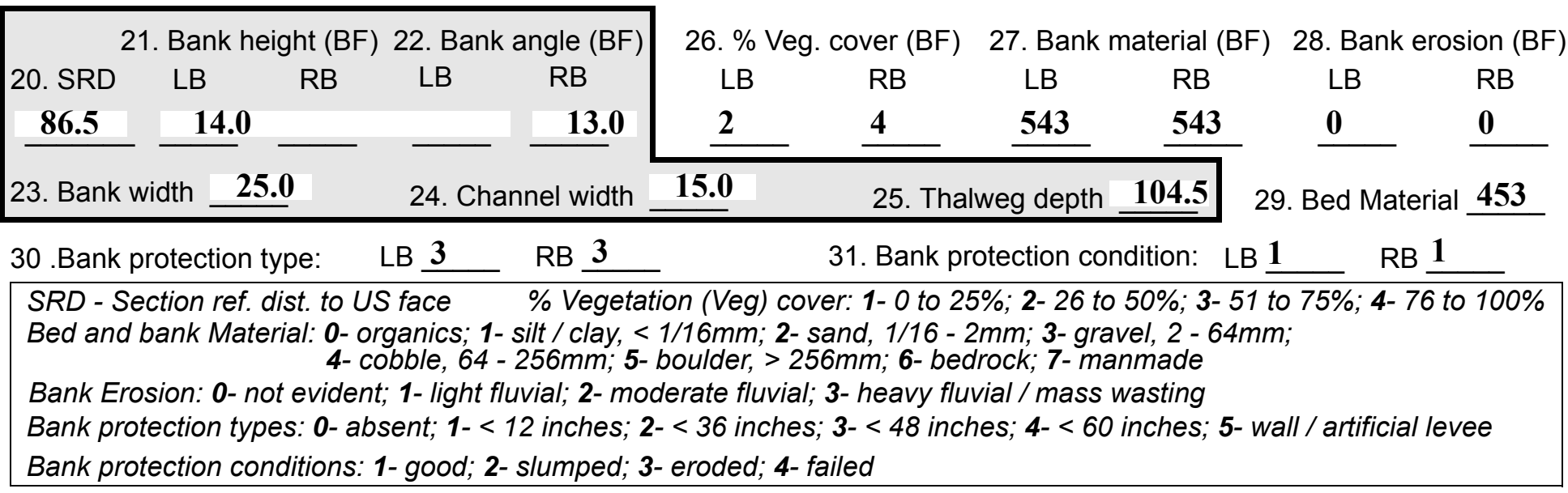

32. Comments (bank material variation, minor inflows, protection extent, etc.):

\#29: Bed is very well packed with boulders.

\#30: Bank protection within one bridge length is both man-placed and natural. Beyond one bridge length, bank protection is natural. 
33.Point/Side bar present? $\mathbf{N}(Y$ or $N$. if $N$ type ctrl-n pb)34. Mid-bar distance: -

35. Mid-bar width: -

36. Point bar extent: feet (US, UB) to feet (US, UB, DS) positioned $\%$ LB to $\% \mathrm{RB}$

37. Material: -

38. Point or side bar comments (Circle Point or Side; Note additional bars, material variation, status, etc.):

NO POINT BARS

Local point/side bars occur at downstream end of boulders.

39. Is a cut-bank present? $\underline{\mathbf{N}}$ (Y or if $\mathrm{N}$ type ctrl-n cb)

40. Where? - $\quad$ (LB or RB)

41. Mid-bank distance: -

42. Cut bank extent: feet (US, UB) to feet (US, UB, DS)

43. Bank damage: (1- eroded and/or creep; 2- slip failure; 3- block failure)

44. Cut bank comments (eg. additional cut banks, protection condition, etc.):

NO CUT BANKS

45. Is channel scour present? $\mathbf{Y}$ (Y or if $N$ type ctrl-n cs) $\quad$ 46. Mid-scour distance: 25

47. Scour dimensions: Length $\underline{\mathbf{6 0}}$ Width $\underline{\mathbf{1 0}}$ Depth : $\underline{\mathbf{3}} \quad$ Position $\underline{\mathbf{5 0}} \% \mathrm{LB}$ to $\underline{\mathbf{7 0}} \% \mathrm{RB}$

48. Scour comments (eg. additional scour areas, local scouring process, etc.):

Scour is UB; could be a result of scour behind/beside large boulder and contraction through bridge.

Many local scour holes exist behind large boulders.

49. Are there major confluences? $\mathbf{N}$

51. Confluence 1: Distance Confluence 2: Distance 52. Enters on Enters on 54. Confluence comments (eg. confluence name):

NO MAJOR CONFLUENCES
50. How many? -

53. Type(1- perennial; 2- ephemeral)

Type (1-perennial; 2-ephemeral) ( $L B$ or $R B)$

\section{Under Bridge Channel Assessment}

55. Channel restraint (BF)? LB 2

\begin{tabular}{|ccccc}
\hline \multicolumn{2}{|c}{ 56. Height (BF) } & \multicolumn{3}{c}{57 Angle (BF) } \\
LB & RB & LB & RB \\
$\mathbf{3 1 . 5}$ & & & $\mathbf{2 . 0}$ & \\
\hline
\end{tabular}
(1- natural bank; 2- abutment; 3- artificial levee)

58. Bank width (BF) 59. Channel width (Amb) -

61. Material (BF)

LB RB

$\underline{2} \quad \underline{5}$
62. Erosion (BF)

LB RB

$5 \quad 0$

Bed and bank Material: 0- organics; 1- silt / clay, < 1/16mm; 2- sand, 1/16 - 2mm; 3- gravel, 2 - 64mm; 4- cobble, 64 - 256mm; 5- boulder, > 256mm; 6- bedrock; 7- manmade

Bank Erosion: 0- not evident; 1- light fluvial; 2- moderate fluvial; 3- heavy fluvial / mass wasting

64. Comments (bank material variation, minor inflows, protection extent, etc.):

543

\#61: Under conditions of extreme high flows, channel restraint is concrete abutment.

\#63: refer to \#29 comments 
65. Debris and Ice Is there debris accumulation?

67. Debris Potential (1-Low; 2- Moderate; 3- High)

69. Is there evidence of ice build-up? 1

70. Debris and Ice Comments:

1
(Yor $N)$ 66. Where? $\mathbf{N}$

68. Capture Efficiency 1

(1- Upstream; 2- At bridge; 3-Both)

Ice Blockage Potential $\mathbf{N}$
(1- Low; 2- Moderate; 3- High)

(1-Low; 2- Moderate; 3- High)

\begin{tabular}{|l|c|c|c|c|c|c|c|c|}
\hline Abutments & $\begin{array}{c}\text { 71. Attack } \\
\angle \text { (BF) }\end{array}$ & $\begin{array}{c}\text { 72. Slope } \angle \\
\text { (Qmax) }\end{array}$ & $\begin{array}{c}\text { 73. Toe } \\
\text { loc. (BF) }\end{array}$ & $\begin{array}{c}\text { 74. Scour } \\
\text { Condition }\end{array}$ & $\begin{array}{c}75 . \text { Scour } \\
\text { depth }\end{array}$ & $\begin{array}{c}\text { 76. Exposure } \\
\text { depth }\end{array}$ & 77. Material & 78. Length \\
\hline LABUT & & $\mathbf{0}$ & $\mathbf{9 0}$ & $\mathbf{1}$ & $\mathbf{0}$ & - & - & $\mathbf{9 0 . 0}$ \\
\hline RABUT & $\mathbf{1}$ & $\mathbf{0}$ & $\mathbf{9 0}$ & & & $\mathbf{1}$ & $\mathbf{0}$ & $\mathbf{6 7 . 5}$ \\
\hline
\end{tabular}

Pushed: $L B$ or RB

Toe Location (Loc.): 0- even, 1- set back, 2- protrudes

Scour cond.: 0- not evident; 1- evident (comment); 2- footing exposed; 3-undermined footing; 4- piling exposed; 5- settled; 6- failed

Materials: 1- Concrete; 2- Stone masonry or drywall; 3- steel or metal; 4- wood

79. Abutment comments (eg. undermined penetration, unusual scour processes, debris, etc.):

$-$

1

\#73: The vertical, concrete abutment walls are set back. However, during high flows, the abutment walls will act as a channel restraint. The toe of the spill-through slope protrude into the channel at normal flows.

80. Wingwalls: $\begin{array}{lllll} & & & & \\ \text { Exist? Material? } & \text { Scour } & \text { Scour } & \text { Exposure } & \text { Angle? Length? } \\ & \text { Condition? depth? } & \text { depth? } & & \end{array}$

USLWW:

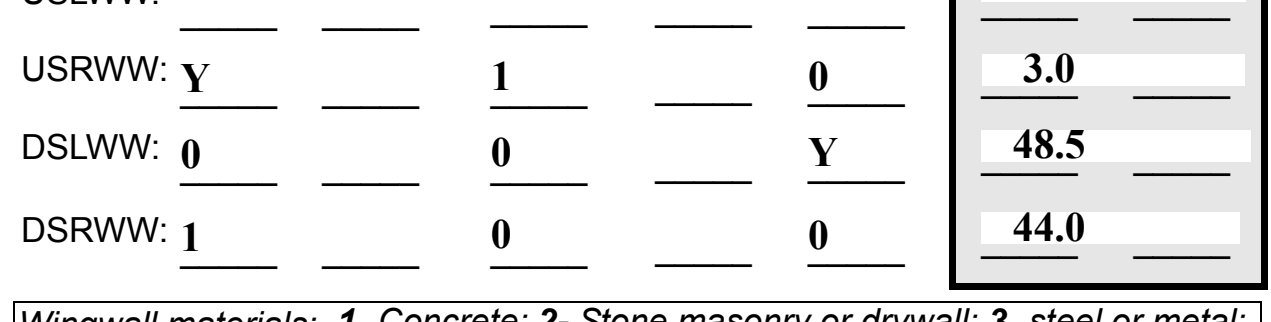

Wingwall materials: 1- Concrete; 2- Stone masonry or drywall; 3- steel or metal; 4- wood

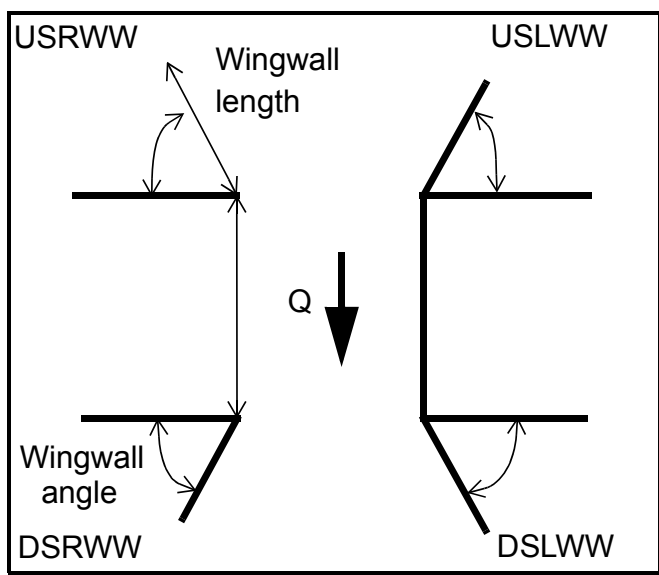

82. Bank / Bridge Protection:

\begin{tabular}{|l|l|l|l|l|l|l|l|c|}
\hline Location & USLWW & USRWW & LABUT & RABUT & LB & RB & DSLWW & DSRWW \\
\hline Type & $\mathbf{0}$ & $\mathbf{0}$ & $\mathbf{Y}$ & $\mathbf{0}$ & $\mathbf{1}$ & $\mathbf{1}$ & $\mathbf{1}$ & $\mathbf{1}$ \\
\hline Condition & $\mathbf{Y}$ & $\mathbf{0}$ & $\mathbf{1}$ & $\mathbf{0}$ & $\mathbf{1}$ & $\mathbf{1}$ & $\mathbf{1}$ & $\mathbf{1}$ \\
\hline Extent & $\mathbf{1}$ & $\mathbf{0}$ & $\mathbf{0}$ & $\mathbf{3}$ & $\mathbf{3}$ & $\mathbf{3}$ & $\mathbf{3}$ & - \\
\hline
\end{tabular}

Bank / Bridge protection types: 0- absent; 1- < 12 inches; 2- < 36 inches; 3- < 48 inches; 4- < 60 inches; 
83. Wingwall and protection comments (eg. undermined penetration, unusual scour processes, etc.):

-
-
-
-
-
3
1
1
3
1
1

\section{Piers:}

84. Are there piers? La (Y or if $N$ type ctrl-n pr)

\begin{tabular}{|l|r|r|r|l|l|l|l|}
\hline \multirow{2}{*}{$\begin{array}{l}85 . \\
\text { Pier no. }\end{array}$} & \multicolumn{3}{|c|}{ width (w) feet } & \multicolumn{3}{c|}{ elevation (e) feet } \\
\cline { 2 - 8 } & w1 & w2 & w3 & e@w1 & e@w2 & e@w3 \\
\hline Pier 1 & & & & $\mathbf{1 5 . 0}$ & $\mathbf{1 3 . 0}$ & $\mathbf{1 0 5 . 0}$ \\
\hline Pier 2 & $\mathbf{8 . 5}$ & $\mathbf{8 . 5}$ & & $\mathbf{1 0 5 . 0}$ & $\mathbf{1 5 . 0}$ & $\mathbf{3 1 . 0}$ \\
\hline Pier 3 & - & - & - & - & - & - \\
\hline Pier 4 & - & - & - & - & - & - \\
-
\end{tabular}

\begin{tabular}{|l|l|l|l|l|}
\hline Level 1 Pier Descr. & \multicolumn{1}{|c|}{1} & \multicolumn{1}{|c|}{2} & 3 & \multicolumn{1}{|c|}{} \\
\hline 86. Location (BF) & rge & walls & & - \\
\hline 87. Type & boul- & and & & - \\
\hline 88. Material & ders & abut & & - \\
\hline 89. Shape & have & ment & N & - \\
\hline 90. Inclined? & been & s. & - & - \\
\hline 91. Attack $\angle$ (BF) & place & & - & - \\
\hline 92. Pushed & d & & - & - \\
\hline 93. Length (feet) & - & - & - & - \\
\hline 94. \# of piles & alon & & - & - \\
\hline 95. Cross-members & g & & - & - \\
\hline 96. Scour Condition & base & & - & - \\
\hline 97. Scour depth & of & & - & - \\
\hline 98. Exposure depth & wing & & - & - \\
\hline
\end{tabular}

LFP, LTB, LB, MCL, MCM, MCR, RB, RTB, RFP

1- Solid pier, 2-column, 3- bent

1-Wood; 2- concrete; 3- metal; 4- stone

1- Round; 2- Square; 3- Pointed

Y-yes; $N$ - no

$L B$ or $R B$

0- none; 1- laterals; 2- diagonals; 3- both

0- not evident; 1- evident (comment);

2- footing exposed; 3- piling exposed;

4- undermined footing; 5- settled; 6-failed 
99. Pier comments (eg. undermined penetration, protection and protection extent, unusual scour processes, etc.):

-
-
-
-
-
-
-
-
-
-

100.

\section{E. Downstream Channel Assessment}

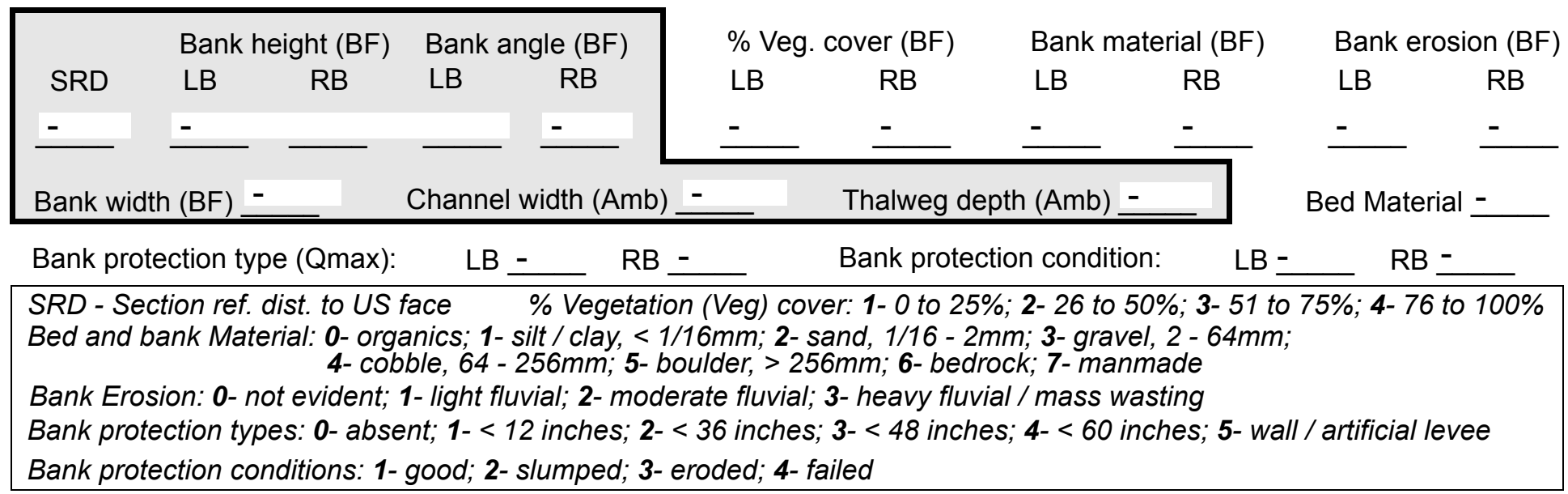

Comments (eg. bank material variation, minor inflows, protection extent, etc.):

-
-
-
-
-
-
-
NO PIERS

101. Is a drop structure present? ( $Y$ or $N$, if $N$ type ctrl-n ds)

102. Distance: - feet
103. Drop: - feet
104. Structure material: (1- steel sheet pile; 2- wood pile; 3- concrete; 4- other)

105. Drop structure comments (eg. downstream scour depth):

4

2

543

543

1

1 
106. Point/Side bar present? $\mathbf{5 4}$ (Y or N. if N type ctrl-n pb)Mid-bar distance: $\mathbf{3}$ Mid-bar width: $\mathbf{0}$

Point bar extent: $\underline{0}$ feet -

(US, UB, DS) to feet $\underline{\mathbf{B a}}$

(US, UB, DS)

DS) positioned $\mathbf{n k}$ $\%$ LB to ero \%RB

Material: sio

Point or side bar comments (Circle Point or Side; note additional bars, material variation, status, etc.):

n due to redirection of local flow by boulders along edge of channel. There also may be some bank steepening (erosion) due to ice.

Bed material: refer to comments of \#29.

Is a cut-bank present? (Y or if $N$ type ctrl- $n$ cb) Where? (LB or $R B)$

Mid-bank distance:

Cut bank extent: feet (US, UB, DS) to feet (US, UB, DS)

Bank damage: (1- eroded and/or creep; 2- slip failure; 3- block failure)

Cut bank comments (eg. additional cut banks, protection condition, etc.):

$\mathbf{N}$

Is channel scour present? ( $Y$ or if $N$ type ctrl-n cs)

Mid-scour distance: NO

Scour dimensions: Length $\underline{\mathbf{D R O}}$ Width $\underline{\mathbf{P}}$ Depth: $\underline{\text { STR }}$

Positioned UC \%LB to $\underline{\text { TU }} \%$ RB

Scour comments (eg. additional scour areas, local scouring process, etc.):

RE

Are there major confluences?

Confluence 1: Distance $\underline{\mathbf{Y}}$

Confluence 2: Distance 160 ( $Y$ or if $N$ type ctrl-n $m c)$ Enters on $\underline{\mathbf{2 0}}$ (LB or RB) Enters on $\underline{\mathbf{D S}}$ (LB or RB)

Confluence comments (eg. confluence name):

$+$

DS

\section{F. Geomorphic Channel Assessment}

107. Stage of reach evolution $\mathbf{9 0}$

1- Constructed

2- Stable

3- Aggraded

4- Degraded

5- Laterally unstable

6- Vertically and laterally unstable 
108. Evolution comments (Channel evolution not considering bridge effects; See HEC-20, Figure 1 for geomorphic descriptors):

100

4

Natural - occurs on outside of bend in channel.

$\mathbf{N}$

$-$

$-$

$-$

$-$ 


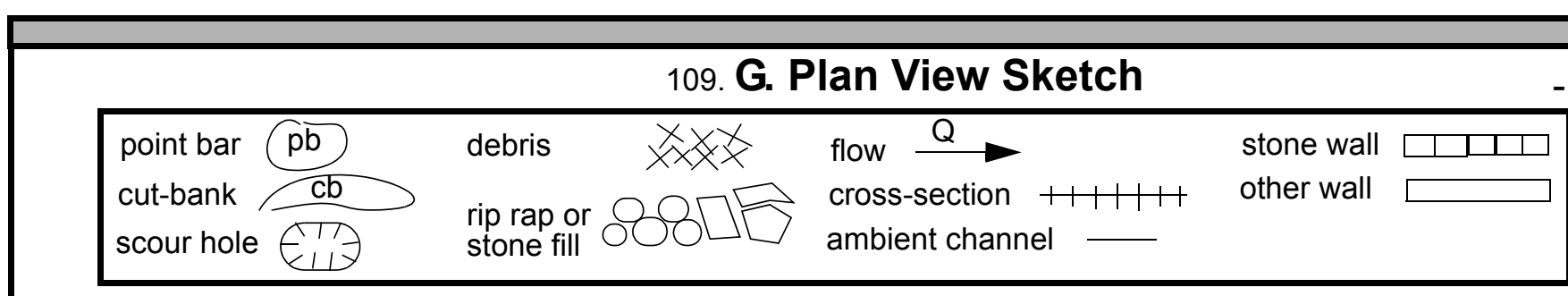


APPENDIX F:

SCOUR COMPUTATIONS 
SCOUR COMPUTATIONS

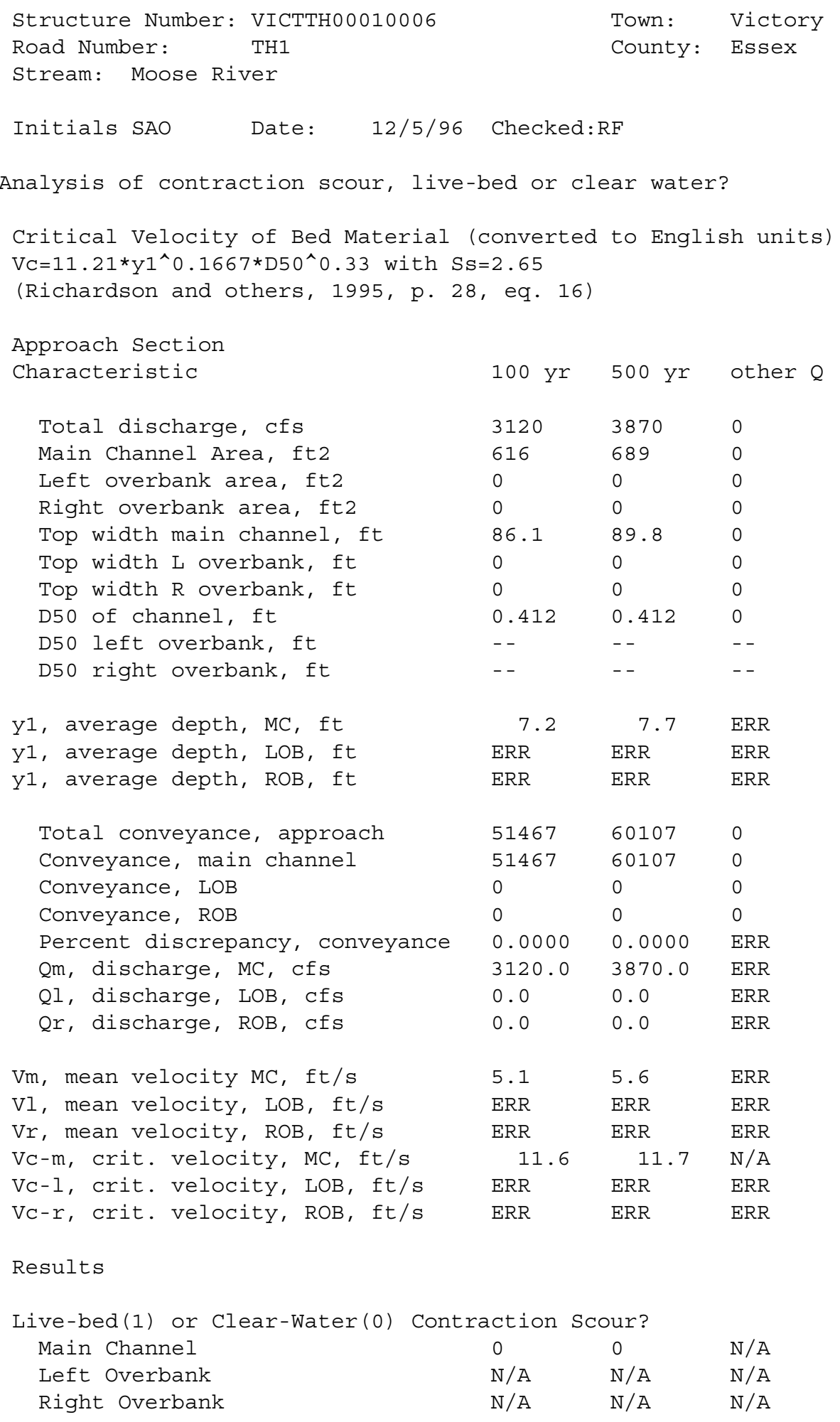


Clear water Contraction Scour in MAIN CHANNEL

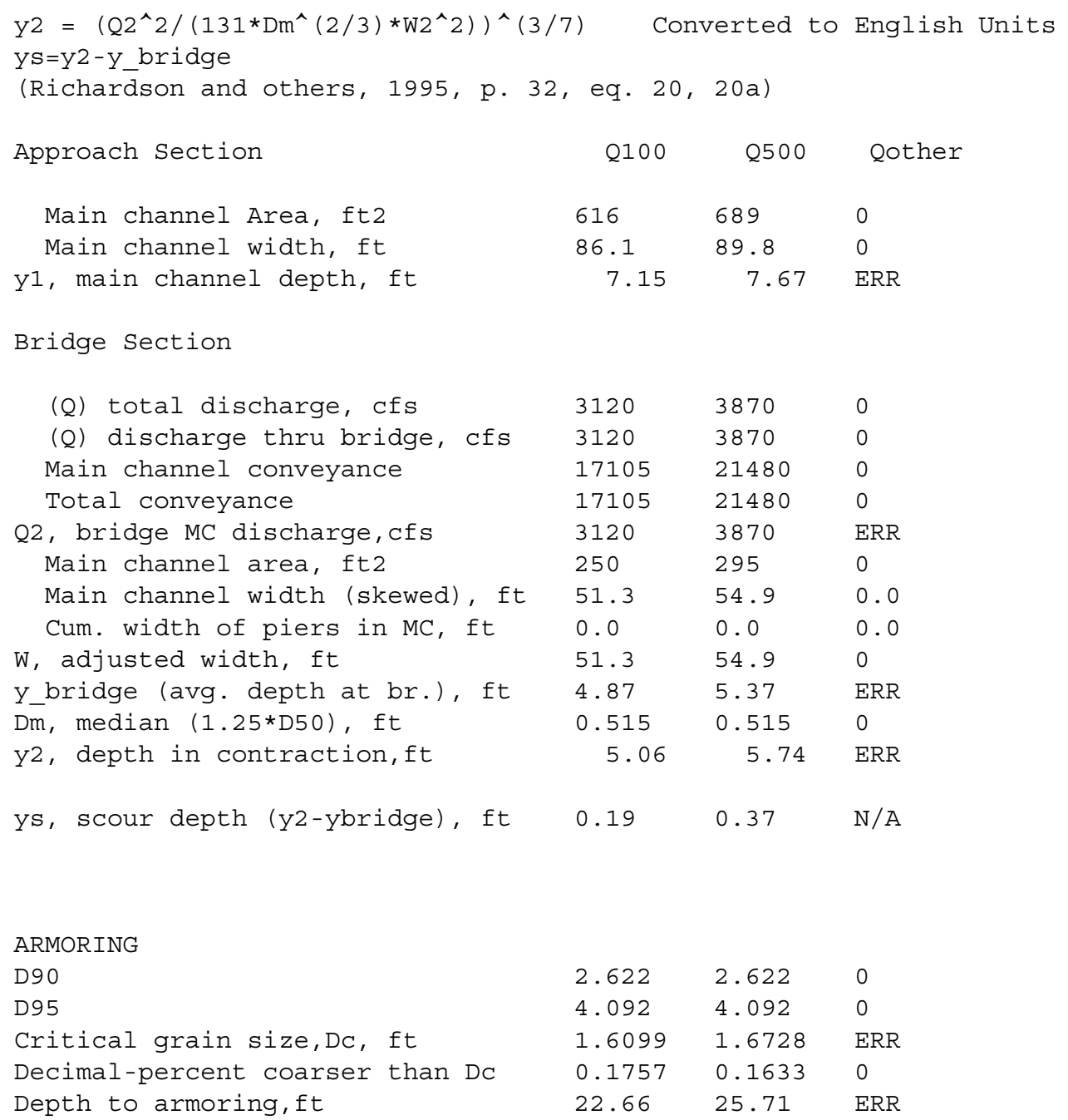


Abutment Scour

Froehlich's Abutment Scour

$\mathrm{Ys} / \mathrm{Y} 1=2.27 * \mathrm{~K} 1 * \mathrm{~K} 2 *\left(\mathrm{a}^{\prime} / \mathrm{Y} 1\right) \wedge 0.43 * \mathrm{Fr} 1 \wedge 0.61+1$

(Richardson and others, 1995, p. 48, eq. 28)

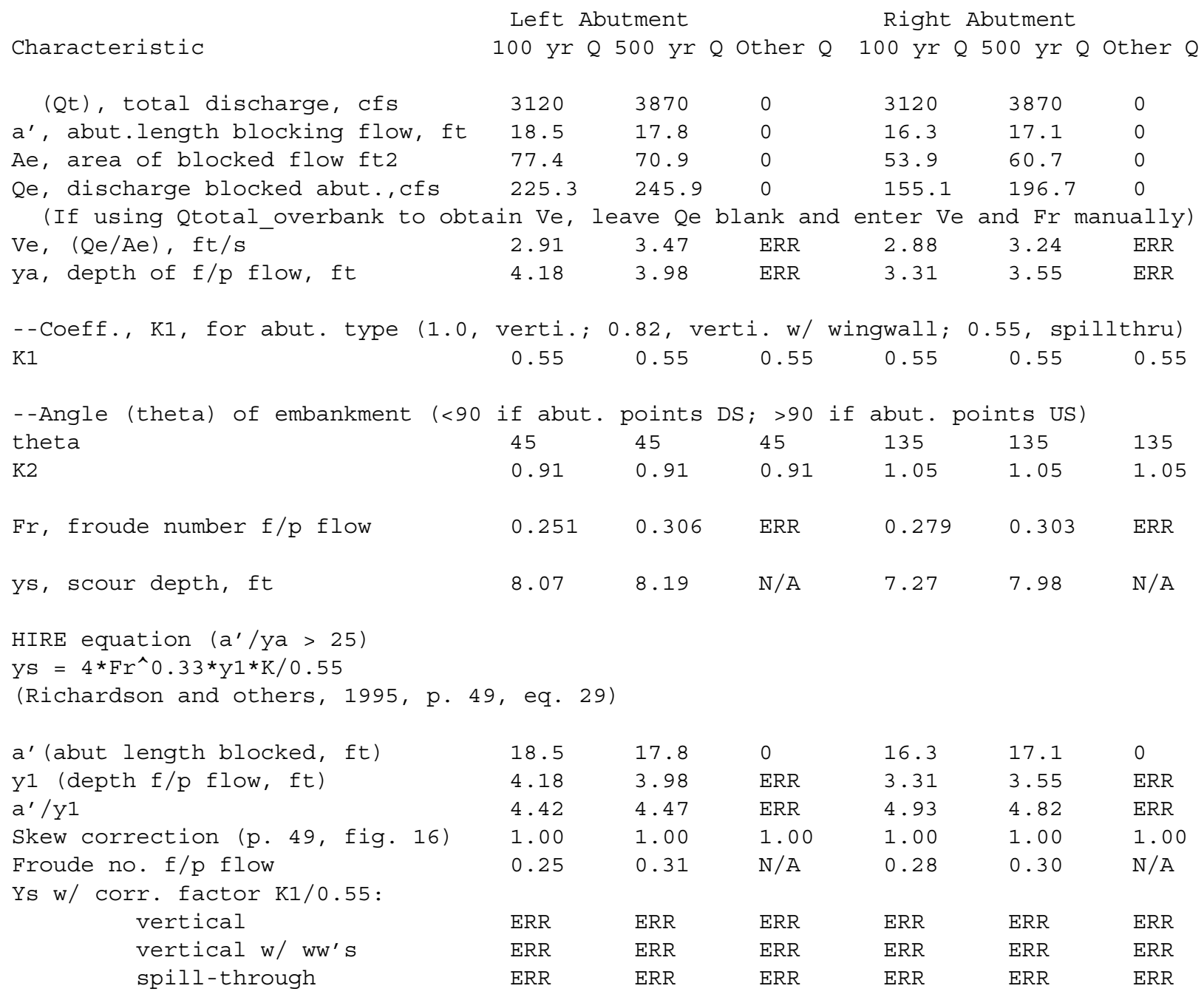




\begin{tabular}{|c|c|c|c|c|c|c|}
\hline \multicolumn{7}{|c|}{$\begin{array}{l}\text { Isbash Relationship } \\
\mathrm{D} 50=\mathrm{Y}^{\star} \mathrm{K} * \mathrm{Fr} r^{\wedge} 2 /(\mathrm{Ss}-1) \text { and } \mathrm{D} 50=\mathrm{Y}^{*} \mathrm{~K} *\left(\mathrm{Fr} r^{\wedge} 2\right)^{\wedge} 0.14 /(\mathrm{Ss}-1) \\
\text { (Richardson and others, 1995, p112, eq. 81,82) }\end{array}$} \\
\hline Characteristic & Q100 & Q500 & \multicolumn{4}{|c|}{ Qother } \\
\hline $\begin{array}{l}\text { Fr, Froude Number } \\
\text { (Fr from the characteristic } V \text { and }\end{array}$ & $\begin{array}{l}1 \\
y\end{array}$ in & $\begin{array}{l}1 \\
\text { tracte }\end{array}$ & $\begin{array}{l}0 \\
\text { ection }\end{array}$ & c, bri & $\begin{array}{l}1 \\
\text { secti }\end{array}$ & 0 \\
\hline$y$, depth of flow in bridge, ft & 4.87 & 5.37 & 0.00 & 4.87 & 5.37 & 0.00 \\
\hline \multicolumn{4}{|c|}{ Median Stone Diameter for riprap at: left abutment } & \multicolumn{3}{|c|}{ right abutment, ft } \\
\hline Fr<=0.8 (vertical abut.) & ERR & $\mathrm{ERR}$ & 0.00 & ERR & ERR & 0.00 \\
\hline Fr>0.8 (vertical abut.) & 2.04 & 2.25 & ERR & 2.04 & 2.25 & ERR \\
\hline Fr<=0.8 (spillthrough abut.) & ERR & $\mathrm{ERR}$ & 0.00 & ERR & ERR & 0.00 \\
\hline Fr>0.8 (spillthrough abut.) & 1.80 & 1.99 & ERR & 1.80 & 1.99 & $\mathrm{ERR}$ \\
\hline
\end{tabular}

